Cochrane Database of Systematic Reviews

\title{
Dietary interventions for phenylketonuria (Review)
}

Poustie VJ, Wildgoose J

Poustie VJ, Wildgoose J.

Dietary interventions for phenylketonuria.

Cochrane Database of Systematic Reviews 2010, Issue 1. Art. No.: CD001304.

DOI: 10.1002/14651858.CD001304.pub2. 
TABLE OF CONTENTS

HEADER

ABSTRACT

PLAIN LANGUAGE SUMMARY

BACKGROUND

OBJECTIVES

METHODS

RESULTS

DISCUSSION

AUTHORS' CONCLUSIONS

ACKNOWLEDGEMENTS

REFERENCES

CHARACTERISTICS OF STUDIES

DATA AND ANALYSES

Analysis 1.1. Comparison 1 PKU participants started on diet at diagnosis: Diet continuation versus discontinuation/relaxation later, Outcome 1 Blood phenylalanine level (micromol/l).

Analysis 1.2. Comparison 1 PKU participants started on diet at diagnosis: Diet continuation versus discontinuation/relaxation later, Outcome 2 Weight.

Analysis 1.3. Comparison 1 PKU participants started on diet at diagnosis: Diet continuation versus discontinuation/relaxation later, Outcome 3 Intelligence Quotient (IQ).

Analysis 1.4. Comparison 1 PKU participants started on diet at diagnosis: Diet continuation versus discontinuation/relaxation later, Outcome 4 Calorie intake (kcal $/ \mathrm{kg})$.

Analysis 1.5. Comparison 1 PKU participants started on diet at diagnosis: Diet continuation versus discontinuation/relaxation later, Outcome 5 Protein intake $(\mathrm{g} / \mathrm{kg})$.

Analysis 2.1. Comparison 2 PKU participants on strict diet from diagnosis, later relaxed: Diet re-establishment versus continuation, Outcome 1 Blood phenylalanine level (micromol/l).

Analysis 3.1. Comparison 3 PKU participants at diagnosis: Low-phenylalanine diet versus moderate phenylalanine diet, Outcome 1 Blood phenylalanine level (micromol/l).

Analysis 3.2. Comparison 3 PKU participants at diagnosis: Low-phenylalanine diet versus moderate phenylalanine diet, Outcome 2 Weight (kg).

Analysis 3.3. Comparison 3 PKU participants at diagnosis: Low-phenylalanine diet versus moderate phenylalanine diet, Outcome 3 Intelligence Quotient (IQ).

Analysis 3.4. Comparison 3 PKU participants at diagnosis: Low-phenylalanine diet versus moderate phenylalanine diet, Outcome 4 Calorie intake $(\mathrm{kcal} / \mathrm{kg})$.

Analysis 3.5. Comparison 3 PKU participants at diagnosis: Low-phenylalanine diet versus moderate phenylalanine diet, Outcome 5 Protein intake $(\mathrm{g} / \mathrm{kg})$.

Analysis 3.6. Comparison 3 PKU participants at diagnosis: Low-phenylalanine diet versus moderate phenylalanine diet, Outcome 6 Phenylalanine intake (mg/day).

WHAT'S NEW

HISTORY

CONTRIBUTIONS OF AUTHORS

DECLARATIONS OF INTEREST

SOURCES OF SUPPORT

NOTES

INDEX TERMS

1

2

3

3

3

5

6

7

7

8

10

14

15

16 
[Intervention Review]

\section{Dietary interventions for phenylketonuria}

Vanessa J Poustie ${ }^{1}$, Joanne Wildgoose ${ }^{2}$

1Institute of Child Health, University of Liverpool, Alder Hey Children's NHS Foundation Trust, Liverpool, UK. 2Physio Corridor, Level 1, Bradford Royal Infirmary, Bradford, UK

Contact address: Vanessa J Poustie, Institute of Child Health, University of Liverpool, Alder Hey Children's NHS Foundation Trust, Eaton Road, Liverpool, Merseyside, L12 2AP, UK. v.poustie@liv.ac.uk.

Editorial group: Cochrane Cystic Fibrosis and Genetic Disorders Group.

Publication status and date: New search for studies and content updated (no change to conclusions), published in Issue 1, 2010.

Citation: Poustie VJ, Wildgoose J. Dietary interventions for phenylketonuria. Cochrane Database of Systematic Reviews 2010, Issue 1. Art. No.: CD001304. DOI: 10.1002/14651858.CD001304.pub2.

Copyright (c) 2010 The Cochrane Collaboration. Published by John Wiley \& Sons, Ltd.

\section{A B S T R A C T}

\section{Background}

Phenylketonuria is an inherited disease treated with dietary restriction of the amino acid phenylalanine. The diet is initiated in the neonatal period to prevent mental handicap; however, it is restrictive and can be difficult to follow. Whether the diet can be relaxed or discontinued during adolescence or should be continued for life remains a controversial issue, which we aim to address in this review.

\section{Objectives}

To assess the effects of a low-phenylalanine diet commenced early in life for people with phenylketonuria. To assess the possible effects of relaxation or termination of the diet on intelligence, neuropsychological outcomes and mortality, growth, nutritional status, eating behaviour and quality of life.

\section{Search methods}

We searched the Cochrane Cystic Fibrosis and Genetic Disorders Group Trials Register comprising references identified from comprehensive electronic database searches, handsearches of relevant journals and abstract books of conference proceedings.

Most recent search of the Inborn Errors of Metabolism Trials Register: 05 March 2009.

\section{Selection criteria}

All randomised or quasi-randomised controlled trials comparing a low-phenylalanine diet to relaxation or termination of dietary restrictions in people with phenylketonuria.

\section{Data collection and analysis}

Two authors independently assessed study eligibility and methodological quality, and subsequently extracted the data.

\section{Main results}

We included four studies in this review (251 participants), and found few significant differences between treatment and comparison groups for the outcomes of interest. Blood phenylalanine levels were significantly lower in participants with phenylketonuria following a lowphenylalanine diet compared to those on a less restricted diet, mean difference (MD) at three months -698.67 (95\% confidence interval (Cl) -869.44 to -527.89). Intelligence quotient was significantly higher in participants who continued the diet than in those who stopped the diet, MD after 12 months 5.00 ( $95 \% \mathrm{Cl} 0.40$ to 9.60). However, these results came from a single study. 


\section{Authors' conclusions}

The results of non-randomised studies have concluded that a low-phenylalanine diet is effective in reducing blood phenylalanine levels and improving intelligence quotient and neuropsychological outcomes. We were unable to find any randomised controlled studies that have assessed the effect of a low-phenylalanine diet versus no diet from diagnosis. In view of evidence from non-randomised studies, such a study would be unethical and it is recommended that low-phenylalanine diet should be commenced at the time of diagnosis. There is uncertainty about the precise level of phenylalanine restriction and when, if ever, the diet should be relaxed. This should be addressed by randomised controlled studies.

\section{PLAIN LANGUAGE SUMMARY}

\section{Using diet to manage phenylketonuria}

Phenylketonuria (PKU) is an inherited disease that affects the breakdown of protein. High levels of the amino acid phenylalanine in the blood damage the nervous system and can also lead to mental handicap. Newborn babies with PKU are given a special diet low in phenylalanine. Other studies suggest that a low-phenylalanine diet can reduce blood phenylalanine levels. The review includes four studies, but we were not able to combine many results. Results from one study showed that blood phenylalanine levels were lower and intelligent quotient higher for people on a special diet. We recommend that a low-phenylalanine diet should be followed from the time of diagnosis. More research is needed to show if it is safe to relax this diet later on. 


\section{B A C K G R O U N D}

\section{Description of the condition}

Phenylketonuria (PKU) is an inherited disease which affects 100 cases per million live births in Caucasian and Asian populations (Scriver 1995). PKU is characterised by an absence or deficiency of phenylalanine hydroxylase (a liver enzyme involved in the breakdown of the essential amino acid phenylalanine to tyrosine). In classical PKU there is a total, or almost total, deficiency of phenylalanine hydroxylase leading to high blood phenylalanine concentrations of $1200 \mu \mathrm{mol} / \mathrm{l}$ or more (Scriver 1995). In some cases blood phenylalanine concentrations are persistently raised above $400 \mu \mathrm{mol} / \mathrm{l}$, but not to the levels seen in classical PKU, although some degree of phenylalanine hydroxylase activity remains present. These conditions are called the hyperphenylalaninaemias. However, for the purpose of this review the term PKU will be used to include both classical PKU and the hyperphenylalaninaemias.

In infants with PKU, the blood phenylalanine concentration is within the normal range at birth, but becomes elevated, usually within several hours to a few days of commencing a normal dietary intake. This can lead to neurological damage and mental retardation if left untreated (Paine 1957). In infants with less severe phenylalanine hydroxylase deficiency the occurrence of brain damage is more variable.

\section{Description of the intervention}

The results of a number of cohort studies have indicated that dietary treatment of PKU is effective in preventing or reducing mental handicap, if initiated within the first twenty days of life (MRC1 1993). However, the recommended diet has several disadvantages, as it is a difficult regimen to follow and requires regular support from a specialist team. In addition, the dietary restrictions may result in inappropriate eating behaviour patterns and nutritional deficiencies (Smith 1994). The aim of the diet is to achieve blood phenylalanine concentrations within the recommended levels and to promote normal growth and development (MRC1 1993). This is achieved by the exclusion of high protein foods, which contain high concentrations of phenylalanine, for example meat, fish, cheese and eggs. However, phenylalanine is an essential amino acid and cannot be totally excluded from the diet. Therefore, the appropriate daily phenylalanine intake is provided by carefully measured quantities of foods containing lower concentrations of phenylalanine, for example, potatoes, baked beans and cereal products. These are called exchanges. The dietitian provides people with PKU and their families with a list of exchanges; the number of these varies according to the person's blood phenylalanine concentrations, which are regularly monitored. Foods that contain minimal amounts of phenylalanine, for example some fruits and vegetables, fats and sugar, can be taken freely. Special prescribable low-protein products are available in some countries to supplement the energy content and increase the variety of the diet. In addition to the dietary restrictions, people with PKU must consume a very low phenylalanine or phenylalanine-free amino acid supplement on a daily basis. This replaces the essential amino acids and other nutrients, which may be deficient in the restricted diet (Dixon 1994). Care should be taken, as some of the amino acid supplements require additional supplementation with vitamins and minerals. In addition, these products are generally considered to be unpalatable; therefore close monitoring of compliance and the nutritional adequacy of the diet is essential to ensure adequate growth and to avoid nutritional deficiencies.

It is accepted that all children with PKU should be started on the diet as early as possible, but controversies exist around the issue of when, if at all, it is safe for dietary restrictions to be lifted or relaxed (Michals 1988). Previously, different recommendations have been made on the most appropriate age at which relaxation or discontinuation of the diet should occur, for example by the time the child with PKU has started school or when the child has reached early adolescence. However, recent research has indicated that older children and adults with PKU who have discontinued dietary restrictions may experience upper motor neurone disturbances (MRC2 1993). Magnetic resonance imaging has also shown that high blood concentrations of phenylalanine in later childhood and adulthood can result in changes to the white matter of the brain (Smith 1994). In light of these studies, the Medical Research Council Working Party on Phenylketonuria issued a series of recommendations on the dietary management of PKU in the United Kingdom in 1993 (MRC1 1993). Similar recommendations are followed in other countries (Fisch 1997).

\section{Why it is important to do this review}

People with PKU have received inconsistent advice about when to stop or relax dietary treatment since Bickel first introduced the diet (Bickel 1953). This has resulted in a population of people with PKU who have followed a variety of levels of dietary restrictions over differing lengths of time.

\section{OB JECTIVES}

The aim of this review is to examine evidence that in people with PKU:

1. a low-phenylalanine diet started early in infancy improves neuropsychological performance and intelligence, and affects a number of other outcomes (listed under 'Types of outcome measures' below);

2. relaxation or discontinuation of dietary treatment in PKU has an adverse effect on neuropsychological performance and intelligence, and a number of other outcomes (listed under 'Types of outcome measures' below).

\section{METHODS}

\section{Criteria for considering studies for this review}

\section{Types of studies}

Randomised controlled trials (RCTs), both published and unpublished. Trials, where quasi-randomisation methods such as alternation are used, will be included in future updates of this review if there is sufficient evidence that the treatment and comparison groups were comparable in terms of clinical and nutritional status.

\section{Types of participants}

Individuals of any age with phenylketonuria and other forms of phenylalanine hydroxylase deficiency, diagnosed by the Guthrie test or another recognised, validated screening test and in whom dietary intervention was commenced early in life. 


\section{Types of interventions}

Restriction of dietary phenylalanine and administration of phenylalanine-free or very low phenylalanine amino acid supplement initiated early in life as advised by a specialist PKU team and either continued for life or relaxed or discontinued at any point during the life of the person with PKU. This intervention being compared to unrestricted diet or less strict levels of phenylalanine restriction (with or without administration of very low phenylalanine or phenylalanine-free amino acid supplements).

\section{Types of outcome measures}

\section{Primary outcomes}

1. Blood phenylalanine concentration

2. Measures of neuropsychological performance

3. Measures of intelligence

\section{Secondary outcomes}

1. Blood tyrosine concentration

2. Weight gain or body mass index or z scores or centiles or other indices of nutritional status or growth

3. Energy and nutrient intake

4. Measures of eating behaviour

5. Measures of quality of life

6. Death

\section{Search methods for identification of studies}

Relevant studies were identified from the Group's Inborn Errors of Metabolism Trials Register using the term: diet.

The Inborn Errors of Metabolism Trials Register is compiled from electronic searches of the Cochrane Central Register of Controlled Trials (Clinical Trials) (updated each new issue of The Cochrane Library), quarterly searches of MEDLINE and the prospective handsearching of one journal - Journal of Inherited Metabolic Disease. Unpublished work was identified by searching through the abstract books of the Society for the Study of Inborn Errors of Metabolism conference and the SHS Inborn Error Review Series. For full details of all searching activities for the register, please see the relevant section of the Cystic Fibrosis and Genetic Disorders Group Module.

Additional RCTs were found from reference lists. Manufacturers of the phenylalanine-free and very low phenylalanine protein supplements were contacted to ask if they had data from published and unpublished RCTs on file.

Date of the most recent search of the Group's Inborn Errors of Metabolism Trials Register: 05 March 2009.

\section{Data collection and analysis}

\section{Selection of studies}

The two authors independently selected the studies to be included in the review.

\section{Data extraction and management}

Both authors independently extracted data.

\section{Assessment of risk of bias in included studies}

The two authors independently assessed the methodological quality of the included studies using a method described by Schulz (Schulz 1995) and related this to the risk of bias. This method focuses on four areas: allocation concealment; generation of the randomisation sequence; intention-to-treat analysis; and blinding. The authors graded the concealment of allocation to the investigators of participants to treatment groups as being adequate, unclear or inadequate. The authors also used the same three categories to assess the method used to generate the randomisation sequence. In both cases, an 'adequate' grade related to a low risk of bias, an 'unclear' grade related to an unclear risk of bias and an 'inadequate' grade related to a high risk of bias. Use of an intention-to-treat analysis was assessed using the categories: adequate; unclear; or exclusions (i.e. participants were excluded from the final analysis), where adequate related to a low risk of bias, unclear to an unclear risk of bias and exclusions to a high risk of bias. The authors considered the level of blinding, although they noted that it is difficult to blind participants when treatment involves dietary manipulation. However, it should be possible for the investigators to be blinded to which treatment group the participant is in, even if the participant is aware of group allocation. The more people that were blinded to an intervention led to a lower risk of bias. Had the two authors disagreed about the quality of a study, then they would have resolved the disagreement by discussion until they reached a consensus.

\section{Measures of treatment effect}

For binary outcome measures we planned to calculate a pooled estimate of the treatment effect for each outcome across studies, (the odds of an outcome among treatment allocated participants to the corresponding odds among controls). For continuous outcomes, we recorded either mean change from baseline for each group or mean post-treatment or intervention values and standard deviation or standard error for each group. Where possible, we calculated a pooled estimate of treatment effect by calculating the mean difference (MD) with 95\% confidence intervals (CI).

Outcome data were grouped into those measured at one, three, six, twelve months and annually thereafter. If outcome data are recorded at other time periods, we would consider examining these as well.

\section{Unit of analysis issues}

Where the authors included studies of cross-over design in the review, they ideally used paired data in the analysis to allow a within-individual comparison of the intervention. Where such data were not available, the authors used data from the first arm of the study only in the analysis. If this was not possible, they employed an unsatisfactory approach of using the combined results, thereby ignoring the cross-over design (Elbourne 2002).

\section{Dealing with missing data}

In order to allow an intention-to-treat analysis, we will seek data on the number of participants by allocated treatment group, irrespective of compliance and whether or not the participant was later thought to be ineligible or otherwise excluded from treatment or follow up. 


\section{Assessment of heterogeneity}

The authors planned to test for heterogeneity between study results, using a standard chi-squared test.

\section{Subgroup analysis and investigation of heterogeneity}

The authors may perform subgroup analysis (stratifying according to type of control group(s) used, age and level of dietary restriction) for future updates.

\section{Sensitivity analysis}

The authors planned to perform a sensitivity analysis based on the methodological quality of the studies, including and excluding quasi-randomised studies.

\section{RE S U L T S}

\section{Description of studies}

\section{Results of the search}

Thirty-nine references to twenty-two separate studies were identified in the searches.

\section{Included studies}

We included four studies (19 references) in this review, with a total of 251 participants (Clarke 1987; Griffiths 1998; Holtzman 1975; US/PKU Collaborative). Two of these studies employed a crossover design (Clarke 1987; Griffiths 1998). Combined group data only were available from these two studies, which meant that the unsatisfactory approach of ignoring the cross-over design had to be employed to allow these data to be included in the analysis. The study by Holtzman investigated the effects of termination of lowphenylalanine diet at four years of age (Holtzman 1975). The study by Clarke looked at the effect of returning to low-phenylalanine diets in children who had previously relaxed their diet. It was noted that two of the participants who were included in the study had actually continued on a low-phenylalanine diet before starting the study (Clarke 1987). The study by Griffiths investigated the effect of increasing phenylalanine intake in children who had continued on a low-phenylalanine diet since diagnosis (Griffiths 1998). The US/ PKU collaborative study, a large, multicentre, randomised study, investigated the use of a strict low-phenylalanine diet compared to a moderately strict low-phenylalanine diet in newly diagnosed children with PKU (US/PKU Collaborative). The majority of the children started the diet early in life; however, in some participants the diet was not initiated for up to 121 days, which would be considered late according to current recommendations. The participants were followed up regularly until their sixth birthdays, when half were randomised to continue the diet and half were randomised to terminate the diet. The participants then continued to be monitored until, in some cases, into adulthood.

\section{Excluded studies}

Eighteen studies (20 references) were excluded from the review. Full details for the reasons for exclusion can be found in the tables (Characteristics of excluded studies).

\section{Risk of bias in included studies}

\section{Allocation}

Generation of randomisation sequence was adequate (with a low risk of bias) in only one of the included studies (US/PKU Collaborative). In this study treatment groups were "randomly formed" using table of random numbers. Generation of randomisation sequence was unclear in the remaining three included studies leading to an unclear risk of bias for these studies (Clarke 1987; Griffiths 1998; Holtzman 1975).

Allocation concealment was not discussed in two of the studies, which therefore had an unclear risk of bias (Clarke 1987; Holtzman 1975). Allocation concealment was judged adequate in two studies; we therefore judged these studies to have a low risk of bias (Griffiths 1998; US/PKU Collaborative). In the Griffiths study, the usual formula and experimental product were both prepared and coded by pharmaceutical company and the key to the code kept by a senior member of the hospital medical staff (Griffiths 1998). In the US PKU Collaborative study the allocation schedule was produced by project staff in telephone contact with local clinic staff at participating clinics (US/PKU Collaborative).

\section{Blinding}

Two studies were triple-blind, which was achieved by the participants continuing on their usual diet but with the phenylalanine content of the diet manipulated by using additional supplements (Clarke 1987; Griffiths 1998). We therefore judge these studies to have a low risk of bias for blinding of participants, clinicians and the outcome assessors. The other two studies did not blind the participants or the clinicians, but the outcome assessors were blinded to treatment groups; we therefore judge these to have a low risk of bias for the outcome assessors, but a high risk of bias from lack of blinding of the participants and clinicians (Holtzman 1975; US/PKU Collaborative).

\section{Incomplete outcome data}

Intention-to-treat analysis was employed in two of the studies, so we judged these to have a low risk of bias (Clarke 1987; Griffiths 1998). We judge the other two studies to have an unclear risk of bias, since there were several drop outs from the studies, but reasons for these were briefly described in the published papers (Holtzman 1975; US/PKU Collaborative). In one study, data on some of the participants were missing at several of the intermediate time points and at the end of the study (Holtzman 1975). In the US PKU study, a relatively high proportion of participants were lost to follow up and some participants swapped groups after randomisation (US/PKU Collaborative). In addition, many of the study reports combine the results of the groups. This makes analysis difficult or impossible. We have contacted the principal investigator to obtain further details of the individual patient data; however, as yet, this has been unsuccessful.

\section{Effects of interventions}

\section{Primary outcomes}

\section{Blood phenylalanine concentration}

This outcome was measured in all of the studies. The US/PKU collaborative study measured this outcome on a regular basis for up to 12 years (US/PKU Collaborative). The analysis shows that blood phenylalanine concentrations were significantly lower in the 
participants on the low-phenylalanine diet than those on a less restricted diet; MD at three months was $-698.67(95 \% \mathrm{Cl}-869.44$ to $527.89)$, based on the results of two studies. In the study comparing a low-phenylalanine diet to a less restricted diet from diagnosis, the blood phenylalanine concentrations were significantly lower in the participants on the low-phenylalanine diet. However, these results are based on only one study (US/PKU Collaborative).

\section{Blood tyrosine concentration}

This outcome was not measured in any of the studies.

\section{Weight gain and other measures of nutritional status}

This outcome was measured in only two studies (Holtzman 1975; US/PKU Collaborative). The US/PKU collaborative study measured weight, height and head circumference of participants over four years (US/PKU Collaborative). Unfortunately, they only reported the combined results of the treatment and control groups, but we are trying to obtain the individual data from the trialists. However, data were available on weights of the two groups of participants for the first year. In the study by Holtzman, the number of participants in each group was very small and no standard deviations were reported (Holtzman 1975). It was reported that height and head circumference data were also collected in this study, although the data were not presented in the published report. No significant differences were found between mean weights of the two groups at any time point.

\section{Neuropsychological performance}

More than 30 different assessments of neuropsychological performance were carried out in the four studies. Only three of the measures were used in more than one study, although final data from these assessments were not available. Therefore, this outcome was not assessed.

\section{Intelligence quotient}

Three of the studies assessed intelligence quotient (IQ) (Clarke 1987; Holtzman 1975; US/PKU Collaborative). One study did not report the results of the IQ test, although we have contacted the trialists to gain further information (Clarke 1987). Another study did not provide standard deviations for the results (Holtzman 1975). The US/PKU collaborative study found no significant difference between the IQ of participants, who were initiated on a strict low-phenylalanine diet at diagnosis, compared to those who received a less strict low-phenylalanine diet from diagnosis (US/ PKU Collaborative). However, following the second randomisation at six years of age, those participants who were randomised to continue the low-phenylalanine diet achieved a higher IQ than those who were randomised to discontinue the diet. This result was significant after 12 months, MD 5.00 ( $95 \% \mathrm{Cl} 0.40$ to 9.60).

\section{Energy \& protein intake}

Energy and protein intake were assessed in only one of the studies; no significant differences were found between the treatment and comparison groups (US/PKU Collaborative). This study also assessed median phenylalanine intakes over six-monthly periods between the ages of 15 months and 6 years. The children in the group receiving the strictly controlled diet had significantly lower median phenylalanine intakes than those on the less strictly controlled diet. It should be noted that these results are based on data from one study only (US/PKU Collaborative).

\section{Secondary outcomes}

\section{Eating behaviour}

This outcome was not measured in any of the studies.

\section{Quality of life}

This outcome was not measured in any of the studies.

\section{Mortality}

This outcome was not measured in any of the studies.

\section{DISCUSSION}

The recommended diet for the treatment of PKU is very restricted. This has implications for the nutritional status, growth and quality of life of people with PKU. Due to the relatively small numbers of people with PKU, most studies involve only small numbers of participants. This is reflected in the studies considered in this review, with the maximum number of participants in a study being 216, although the data from all these participants were not included in the published report (US/PKU Collaborative). Several of the included studies did not provide details on allocation concealment or generation of randomisation sequence. Only two of the four studies employed an intention-to-treat analysis (Clarke 1987; Griffiths 1998). As would be expected, blood phenylalanine concentration, which was assessed in all the studies, was found to be significantly higher in people with PKU on a relaxed phenylalanine diet than in those on a low-phenylalanine diet. The outcome measures used to assess neuropsychological performance varied from study to study, and it was therefore impossible to combine the results of the studies statistically. The published reports of these studies confounded the situation further by omitting some data.

Only one study investigated the effects of different levels of phenylalanine restriction commenced at diagnosis (US/PKU Collaborative). This study failed to find any significant results other than for blood phenylalanine level and median phenylalanine intake during the first six years of the study. The second stage of this study, which assessed the effect of continuation or termination of the diet at six years of age, found a significant difference between the IQ of those participants who continued the diet compared to those who terminated the diet. This suggests that continuation of the low phenylalanine diet has a beneficial effect on IQ. The remaining studies also investigated the effect of terminating or recommencing the diet at some point later in life, after the diet had been initiated at diagnosis, although we were unable to combine any further results for IQ with those of the US/PKU collaborative study (US/PKU Collaborative). We know from sources of evidence other than RCTs, that a high proportion of children with PKU who do not receive any dietary manipulation develop mental handicap and neurological impairment (MRC2 1993). It would thus be unethical to withhold treatment from people with PKU at diagnosis; however, it may be useful to study the level of restriction required from diagnosis in a study similar to that of the US/PKU collaborative study (US/PKU Collaborative). It is disappointing that the studies available included only small numbers of participants and have not followed them into adulthood. 


\section{AUTHORS' CONCLUSIONS}

\section{Implications for practice}

Due to the lack of good quality RCTs in this review, no conclusions can be drawn about the effectiveness of specific dietary interventions in PKU. As a result of the concerns about mental handicap and neurological damage in untreated PKU, current recommendations to commence a low-phenylalanine diet at diagnosis should continue to be observed. However, there is a lack of clear evidence about the precise level of phenylalanine restriction or when, if ever, the restricted diet could be relaxed. A large, well-designed, adequately-powered RCT is necessary to provide further information. Many centres would need to be involved to achieve this. Therefore, it is recommended that people with PKU should not be entered into small studies, which would then exclude them from entering into a larger study.

\section{Implications for research}

A large, well-designed, adequately-powered, randomised, controlled, double-blind study is necessary to assess the effect of termination of dietary restrictions in PKU. Careful consideration should be given to the inclusion criteria. It may also be useful to assess the effect of different levels of dietary restrictions initiated from diagnosis. Due to the low incidence of PKU in the population, it is essential that any such study be multicentre and possibly international. It would be necessary to ascertain which outcome measures are most appropriate, and to reach a consensus on which measures of intelligence and neuropsychological performance should be used. It would also be beneficial if people with PKU, or their parents, could be involved in the design of the study to ensure that the most important and relevant aspects are considered.

\section{ACKN O WLEDGEMENTS}

We would like to thank Mrs Patricia Rutherford for her contribution to the original review and updates up until May 2007.

We thank the following experts in metabolic disease for commenting on the review:

Professor N Buist, Oregon, USA

Dr C Davidson, Liverpool, UK

Dr B Wilcken, Sydney, Australia

Professor R Koch, Los Angeles, USA

Dr I Smith, London, UK

Dr J Collins, London, UK

Dr J Walter, Manchester, UK

We also thank $\operatorname{Dr}$ D. Isherwood, Royal Liverpool Children's Hospital, UK, for assisting in the handsearching of the Journal of Inherited Metabolic Disease, and The British Dietetic Association for providing computer equipment used in the production of this review. We also thank Ms Vida Rahmani and Mrs Cathy Corlett for providing invaluable consumer input, and Professor F. Cockburn and $\operatorname{Dr}$ A. Harvie for providing additional trial data. 


\section{R E F E R E N C E S}

\section{References to studies included in this review}

Clarke 1987 \{published data only\}

Clarke JTR, Gates RD, Hogan SE, Barrett M, MacDonald GW. Neuropsychological studies on adolescents with phenylketonuria returned to phenylalanine-restricted diets. American Journal of Mental Retardation 1987;92(3):255-62.

Griffiths 1998 \{published data only\}

Griffiths P, Smith C, Harvie A. Transitory

hyperphenylalaninaemia in children with continuously treated phenylketonuria. American Journal of Mental Retardation 1997;102(1):27-36.

Griffiths P, Ward N, Harvie A, Cockburn F. Neuropsychological outcome of experimental manipulation of phenylalanine intake in treated phenylketonuria. Journal of Inherited Metabolic Disease 1998;21(1):29-38.

\section{Holtzman 1975 \{published data only\}}

Holtzman NA, Welcher DW, Mellits ED. Termination of restricted diet in children with phenylketonuria: a randomised controlled study. New England Journal of Medicine 1975;293(22):1121-4.

\section{US/PKU Collaborative \{published data only\}}

Acosta PB, Trahams C, Wellman NS, Williamson M. Phenylalanine intakes of 1- to 6-year old children with phenylketonuria undergoing therapy. American Journal of Clinical Nutrition 1983;38(5):694-700.

Acosta PB, Wentz E, Williamson M. Nutrient intake of treated infants with phenylketonuria. American Journal of Clinical Nutrition 1977;30(2):198-208.

Azen C, Koch R, Friedman E, Wenz E, Fishler K. Summary of findings from the United States Collaborative Study of children treated for phenylketonuria. European Journal of Pediatrics 1996;155(Suppl 1):S29-S32.

Azen CG, Koch R, Friedman EG, Berlow S, Coldwell J, Krause W, et al. Intellectual development in 12-year-old children treated for phenylketonuria. American Journal of Diseases of Children 1991;145(1):35-9.

Dobson JC, Williamson ML, Azen C, Koch R. Intellectual assessment of 111 four-year-old children with phenylketonuria. Pediatrics 1977;60(6):822-7.

Fishler K, Azen CG, Friedman EG, Koch R. School achievement in treated PKU children. Journal of Mental Deficiency Research 1989;33(Pt 6):493-8.

Holm VA, Kronmal RA, Williamson M, Roche AF. Physical growth in phenylketonuria: II. Growth of treated children in the PKU collaborative study from birth to 4 years of age. Pediatrics 1979;63(5):700-7.

Koch R, Azen C, Friedman EG, Williamson ML. Paired comparisons between early treated PKU children and their matched sibling controls on intelligence and school achievement test results at eight years of age. Journal of Inherited Metabolic Disease 1984;7(2):86-90.

Koch R, Azen CG, Friedman EG, Williamson ML. Preliminary report on the effects of diet discontinuation in PKU. Journal of Pediatrics 1982;100(4):870-5.

Koch R, Burton B, Hoganson G, Peterson R, Rhead W, Rouse B, et al. Phenylketonuria in adulthood: a collaborative study. Journal of Inherited Metabolic Disease 2002;25(5):333-6.

Koch R, Friedman E, Williamson M, Azen C, Blaskovics, Parker G. Report from the U.S. Collaborative Study of diet discontinuation in PKU children [abstract]. Proceedings from the 19th International Conference of the Society for the Study of Inborn Errors of Metabolsm;1981; Southampton. 1981:No. 6.

Koch R, Friedman EG, Williamson ML, Azen CG. Preliminary report of the effects of diet discontinuation in phenylketonuria. Journal of Inherited Metabolic Disease 1982;5(Suppl 1):63-4.

Williamson M, Dobson JC, Koch R. Collaborative study of children treated for phenylketonuria: study design. Pediatrics 1977;60(6):815-21.

Williamson ML, Koch R, Azen C, Chang C. Correlates of intelligence test results in treated phenylketonuric children. Pediatrics 1981;68(2):161-7.

Williamson ML, Koch R, Azen C, Chang C. Correlates of intelligence test results in treated phenylketonuric children [abstract]. Proceedings of the 19th International Meeting of the Society for the Study of Inborn Errors of Metabolism; 1981; Southampton. 1981:No. 43

\section{References to studies excluded from this review}

\section{Bentovim 1968 \{published data only\}}

Bentovim A. Controlled observations of phenylketonuric children on and during withdrawal from low phenylalanine diet. Archives of Disease in Childhood 1968;43(232):745-6.

Cleary 2006 \{published data only\}

Cleary MA, Feillet F, White FJ, Vidailhet M, Macdonald A, Grimsley A, et al. Randomised controlled trial of essential fatty acid supplementation in phenylketonuria. European Journal of Clinical Nutrition 2006;60(7):915-20. [MEDLINE: 98240314]

Epstein 1989 \{published data only\}

Epstein CM, Trotter JF, Averbook A, Freeman S, Kutner MH, Elsas LJ. EEG mean frequencies are sensitive indices of phenylalanine effects on normal brain. Electroencephalography and Clinical Neurophysiology 1989;72(2):133-9.

Frankenburg 1973 \{published data only\}

Frankenburg WK, Goldstein AD. Behavioural consequences of increased phenylalanine intake by phenylketonuric children: a pilot study describing a methodology. American Journal of Mental Deficiency 1973;77(5):524-32. 
Kakanoglu 2005 \{published data only\}

Kalkanoglu HS, Ahring KK, Sertkaya D, Moller LB, Romstad A, Mikkelsen I, et al. Behavioural effects of phenylalanine-free amino acid tablet supplementation in intellectually disabled adults with untreated phenylketonuria. Act Paediatrica 2005;94(9):1218-22.

\section{Koff 1979 \{published data only\}}

Koff E, Kammerer B, Boyle P, Pueschel SM. Intelligence and phenylketonuria: effects of diet termination. Journal of Pediatrics 1979;94(4):534-7.

\section{Koletzko 2007 \{published data only\}}

Koletzko B, Sauerwald T, Demmelmair H, Herzog M, von Schenck U, Bohles $\mathrm{H}$, et al. Dietary long-chain polyunsaturated fatty acid supplementation in infants with phenylketonuria: a randomized controlled trial. Journal of Inherited Metabolic Disease 2007;30(3):326-32.

\section{Krause 1985 \{published data only\}}

Krause W, Halminski M, McDonald L, Dembure P, Salvo R, Freides D, et al. Biochemical and neuropsychological effects of elevated plasma phenylalanine in patients with treated phenylketonuria. A model for the study of phenylalanine and brain function in man.. Journal of Clinical Investigation 1985;75(1):40-8.

\section{Levy 2007 \{published data only\}}

Levy HL, Milanowski A, Chakrapani A, Cleary M, Lee P, Trefz FK, et al. Efficacy of sapropterin dihydrochloride (tetrahydrobiopterin, 6R-BH4) for reduction of phenylalanine concentration in patients with phenylketonuria: a phase III randomised placebo-controlled study. Lancet 2007;370(9586):504-10.

\section{Lou 1987 \{published data only\}}

Lou HC, Lykkelund C, Gerdes AM, Udesen H, Bruhn P. Increased vigilance and dopamine synthesis by large doses of tyrosine or phenylalanine restriction in phenylketonuria. Acta Paediatrica Scandinavica 1987;76(4):560-5. [MEDLINE: 87322369]

\section{Pietz 1995 \{published data only\}}

Pietz J, Landwehr R, Kutscha A, Schmidt H, de Sonneville L, Trefz FK. Effect of high-dose tyrosine supplementation on brain function in adults with phenylketonuria. Journal of Pediatrics 1995;127(6):936-43. [MEDLINE: 96101714]

\section{Realmuto 1986 \{published data only\}}

Realmuto GM, Garfinkel BD, Tuchman M, Tsai MY, Chang PN, Fisch RO, et al. Psychiatric diagnosis and behavioural characteristics of phenylketonuric children. Journal of Nervous and Mental Disease 1986;174(9):536-40.

\section{Rey 1996 \{published data only\}}

Rey F, Abadie V, Plainguet F, Rey J. Long-term follow up of patients with classical phenylketonuria after diet relaxation at 5 years of age. European Journal of Pediatrics 1996;155(Suppl 1):S39-S44.

\section{Robertson 2004 \{published data only\}}

* Robertson L, Lee P, Murphy G, Amos A. A trial to assess the effectiveness of a low phenylalanine diet in adults with previously untreated phenylketonuria (PKU) [abstract]. SHS Inborn Error Review Series (Dietary Management of Inborn Errors of Metabolic Disease) 2004;14:10.

Robertson L, Lee P, Murphy G, Amos A. A trial to assess the effectiveness of a low phenylalanine diet in adults with previously untreated phenylketonuria (PKU) [abstract]. SHS Inborn Error Review Series (Dietary Management of Inborn Errors of Metabolic Disease) 2004;14:18.

Robertson L, Murphy G, Amos A, Lee P, Dent C. A randomised control trial of diet in adults with previously untreated phenylketonuria (PKU) [abstract]. Dietary Management of Inherited Metabolic Disease (DMIMD); 2008 April 17-18th; London, UK. 2008:36. [MEDLINE: 98240314]

\section{Schindeler 2007 \{published data only\}}

Schindeler S, Ghosh-Jerath S, Thompson S, Rocca A, Joy P, Kemp A, et al. The effects of large neutral amino acid supplements in PKU: an MRS and neuropsychological study. Molecular Genetics and Metabolism 2007;91(1):48-54.

\section{Schmidt 1994 \{published data only\}}

Schmidt E, Rupp A, Burgard P, Pietz J, Weglage J, de Sonneville L. Sustained attention in adult phenylketonuria: the influence of the concurrent phenylalanine blood level. Journal of Clinical Experimental Neuropsychology 1994;16(5):681-8.

\section{Schmidt 1996 \{published data only\}}

Schmidt E, Burgard P, Rupp A. Effects of concurrent phenylalanine levels on sustained attention and calculation speed in patients treated early for phenylketonuria. European Journal of Pediatrics 1996;155(Suppl 1):S82-S86.

\section{Smith 1998 \{published data only\}}

Smith ML, Hanley WB, Clarke JT, Klim P, Schoonheyt W, Austin V, et al. Randomised controlled trial of tyrosine supplementation on neuropsychological performance in phenylketonuria. Archives of Disease in Childhood 1998;78(2):116-21. [MEDLINE: 98240314]

\section{Additional references}

\section{Bickel 1953}

Bickel H. Influence of phenylalanine intake on phenylketonuria. Lancet 1953;2:812-3.

\section{Dixon 1994}

Dixon M. Disorders of amino acid metabolism, organic acidaemias and uria cycle defects. In: Shaw V, Lawson M editor(s). Clinical Paediatric Dietetics. 1st Edition. Oxford: Blackwell Science, 1994:177-209.

\section{Elbourne 2002}

Elbourne DR, Altman DG, Higgins JPT, Curtin F, Worthington HV, Vail A. Meta-analyses involving cross-over trials: methodological issues. International Journal of Epidemiology 2002;31(1):140-9. 


\section{Fisch 1997}

Fisch RO, Matalon R, Weisberg S, Michals K. Phenylketonuria: Current dietary treatment practices in the United States and Canada. Journal of the American College of Nutrition 1997;16(2):147-51.

\section{Michals 1988}

Michals K, Azen C, Acosta P, Koch R, Matalon R. Blood phenylalanine levels and intelligence of 10 year old children with PKU in the National Collaborative Study. Journal of the American Dietetic Association 1988;88(10):1226-9.

\section{MRC1 1993}

Medical Research Council Working Party on Phenylketonuria. Recommendations on the dietary management of phenylketonuria. Archives of Disease in Childhood 1993;68(3):426-7.

\section{MRC2 1993}

Medical Research Council Working Party on Phenylketonuria. Phenylketonuria due to phenylalanine hydroxylase deficiency: an unfolding story. British Medical Journal 1993;306(6870):115-9.

\section{CHARACTERISTICS OF STUDIES}

Characteristics of included studies [ordered by study ID]

\section{Paine 1957}

Paine RS. The variability and manifestations of untreated patients with phenylketonuria (phenylpyruvic aciduria). Pediatrics 1957;20:290-302.

\section{Schulz 1995}

Schulz KF, Chalmers I, Hayes RJ, Altman DG. Empirical evidence of bias. Dimensions of methodological quality associated with estimates of treatment effects in controlled trials. Journal of the American Medical Association 1995;273(5):408-12.

\section{Scriver 1995}

Scriver CR, Kaufman S, Woo SLC. The hyperphenylalaninaemias. In: Scriver CR, Beaudet AL, Sly WS, Valle D editor(s). The Metabolic and Molecular Bases of Inherited Disease. 7th Edition. New York: McGraw-Hil, 1995:1015-76.

\section{Smith 1994}

Smith I. Treatment of phenylketonuria hydroxylase deficiency. Acta Paediatrica Supplement 1994;407:60-5.

* Indicates the major publication for the study

\section{Clarke 1987}

Methods Randomised triple-blind cross-over controlled study. Duration 10 weeks.

\section{Participants}

9 participants with PKU (3 males, 6 females, mean age 14.4 years). Low phenylalanine diet commenced early infancy. On relaxed diet prior to study.

Interventions

All participants returned to a low-phenylalanine diet for the duration of the study. Participants ingested 3 to 4 capsules per day, each containing $500 \mathrm{mg}$ L-phe during the treatment phase or $500 \mathrm{mg}$ L-alanine during the control phase.

\section{Outcomes}

Blood phenylalanine levels.

The following neuropsychological assessments were carried out at baseline and after the first and second phase: WISC-R, Rosner's auditory analysis test; Raven's coloured progressive matrices; memory for designs; target test; wide range achievement test (arithmetic subtest); finger agnosia; simple reaction time test; choice reaction time test; grooved pegboard test; trail making tests; underlining test; verbal fluency; Stroop colour word interference test.

Notes 2 participants had continued on a phenylalanine-restricted diet prior to commencing the study.

\section{Risk of bias}

\begin{tabular}{lll}
\hline Bias & Authors' judgement & Support for judgement \\
\hline $\begin{array}{l}\text { Adequate sequence gener- } \\
\text { ation? }\end{array}$ & Unclear risk & Method of randomisation not given. \\
\hline Allocation concealment? & Unclear risk & Not discussed. \\
\hline
\end{tabular}


Clarke 1987 (Continued)

\begin{tabular}{lll}
$\begin{array}{l}\text { Blinding? } \\
\text { Participants }\end{array}$ & Low risk & $\begin{array}{l}\text { Triple-blinded. Participants continued on their usual diet but with the pheny- } \\
\text { lalanine content of the diet manipulated by using additional supplements. }\end{array}$ \\
\hline $\begin{array}{l}\text { Blinding? } \\
\text { Clinicians }\end{array}$ & Low risk & Triple-blinded. \\
\hline $\begin{array}{l}\text { Blinding? } \\
\text { Outcome assessors }\end{array}$ & Low risk & Triple-blinded. \\
\hline $\begin{array}{l}\text { Incomplete outcome data } \\
\text { addressed? } \\
\text { All outcomes }\end{array}$ & Low risk & Intention-to-treat analysis was employed. \\
\end{tabular}

\section{Griffiths 1998}

\begin{tabular}{ll} 
Methods & $\begin{array}{l}\text { Randomised, triple-blind, cross-over study. The study was described as being triple-blind as neither the } \\
\text { children, their parents nor the researchers knew which intervention the children received. } \\
\text { Duration } 6 \text { months. }\end{array}$ \\
\hline Participants & $\begin{array}{l}16 \text { participants with PKU (10 males, } 6 \text { females, mean age } 12.6 \text { years). All diagnosed by neonatal period } \\
\text { and were commenced on a low-phenylalanine diet within } 3 \text { weeks of birth. Diet continued from diagno- } \\
\text { sis until study entry. }\end{array}$ \\
\hline Interventions & $\begin{array}{l}\text { Continuation of the low phenylalanine diet in addition to a phenylalanine-free amino acid supplement } \\
\text { for } 3 \text { months followed by a low phenylalanine diet plus an amino acid supplement containing pheny- } \\
\text { lalanine for } 3 \text { months, or vice versa. }\end{array}$ \\
\hline Outcomes & $\begin{array}{l}\text { Blood phenylalanine levels measured at baseline and at the end of the first and second 3-month peri- } \\
\text { od. The following neuropsychological tests were carried out at the same time points: matching familiar } \\
\text { figures; Rey verbal learning; digits forwards; paired-associate learning; Corsi block-tapping; Rey-Davis } \\
\text { manual labyrinth; Purdue pegboard and hole-type steadiness tester. }\end{array}$
\end{tabular}

Notes

\section{Risk of bias}

\begin{tabular}{lll}
\hline Bias & Authors' judgement & Support for judgement \\
\hline $\begin{array}{l}\text { Adequate sequence gener- } \\
\text { ation? }\end{array}$ & Unclear risk & Method of randomisation not given. \\
\hline Allocation concealment? & Low risk & $\begin{array}{l}\text { Usual formula and experimental product prepared and coded by pharmaceuti- } \\
\text { cal company. Key to the code kept by a senior member of the hospital medical } \\
\text { staff. }\end{array}$ \\
\hline $\begin{array}{l}\text { Blinding? } \\
\text { Participants }\end{array}$ & Low risk & $\begin{array}{l}\text { Triple-blinded, neither the children, their parents nor the researchers knew } \\
\text { which intervention the children received. Participants continued on their usu- } \\
\text { al diet but with the phenylalanine content of the diet manipulated by using ad- } \\
\text { ditional supplements. }\end{array}$ \\
\hline $\begin{array}{l}\text { Blinding? } \\
\text { Clinicians }\end{array}$ & Low risk & $\begin{array}{l}\text { Triple-blinded, neither the children, their parents nor the researchers knew } \\
\text { which intervention the children received. }\end{array}$ \\
\hline $\begin{array}{l}\text { Blinding? } \\
\text { Outcome assessors }\end{array}$ & Low risk & $\begin{array}{l}\text { Triple-blinded, neither the children, their parents nor the researchers knew } \\
\text { which intervention the children received. }\end{array}$ \\
\hline
\end{tabular}


Griffiths 1998 (Continued)

Incomplete outcome data Low risk An intention-to-treat analysis was employed.

addressed?

All outcomes

Holtzman 1975

Methods Randomised, controlled parallel study.

Duration 2 years.

Participants

10 participants diagnosed with PKU in the neonatal period and commenced on a low-phenylalanine diet by 1 month of age, were randomised to either continue on the low-phenylalanine diet or to terminate the diet at 4 years of age. 5 participants were randomised to each group and the number of males and females in each group was the same (3 males, 2 females).

\section{Interventions The diet continuation group was continued on a low-phenylalanine diet. Those in the termination} group gradually relaxed the diet following a standard protocol until the diet was unrestricted.

Outcomes

Blood phenylalanine levels were measured at the start of the trial, then at 2, 4, 6 and 8 weeks after the initial time point, and again 6 months, 1 year and 2 years later. Phenylalanine intake was assessed from diet diaries carried out at the same time points as the blood phenylalanine levels. The following physical examinations were carried out when the children were 4, 4.5, 5, 5.5 and 6 years of age: weight gain; height; and head circumference. Neuropsychological examinations were also carried out at these time points and included the following: Stanford Binet intelligence test; the vocabulary; similarities; animal house and the geometric designs subtests of the Wechsler preschool and primary scale of intelligence, auditory and visual sequential memory and auditory reception subtests of the Illinois test of psycholinguistic abilities. A behaviour rating of each child's performance during the test was also obtained.

Notes

\section{Risk of bias}

\begin{tabular}{lll}
\hline Bias & Authors' judgement & Support for judgement \\
\hline $\begin{array}{l}\text { Adequate sequence gener- } \\
\text { ation? }\end{array}$ & Unclear risk & Participants randomly allocated, method not given. \\
\hline Allocation concealment? & Unclear risk & Not discussed. \\
\hline $\begin{array}{l}\text { Blinding? } \\
\text { Participants }\end{array}$ & High risk & $\begin{array}{l}\text { Parents blinded as to which group child was in until time that restricted diet } \\
\text { ceased, at which point they knew treatment group. }\end{array}$ \\
\hline $\begin{array}{l}\text { Blinding? } \\
\text { Clinicians }\end{array}$ & High risk & Not blinded. \\
\hline $\begin{array}{l}\text { Blinding? } \\
\text { Outcome assessors }\end{array}$ & Low risk & Psychological examiner was blinded to diagnosis of PKU. \\
\hline $\begin{array}{l}\text { Incomplete outcome data } \\
\text { addressed? }\end{array}$ & Unclear risk & $\begin{array}{l}\text { Data on some of the participants were missing at several of the intermediate } \\
\text { All outcomes }\end{array}$ \\
\hline
\end{tabular}

\section{US/PKU Collaborative}

Methods Randomised controlled parallel study.


US/PKU Collaborative (Continued)

Duration 12 years, but in some participants, outcomes were assessed into adulthood.

\begin{tabular}{ll}
\hline Participants & $\begin{array}{l}216 \text { infants diagnosed with PKU. Diet was initiated within } 121 \text { days after diagnosis. A relatively high pro- } \\
\text { portion of participants was excluded or withdrew from the study following randomisation. }\end{array}$ \\
\hline Interventions & $\begin{array}{l}\text { At diagnosis participants were randomised to follow either a low-phenylalanine diet or a moder- } \\
\text { ate-phenylalanine diet until they were } 6 \text { years old. At this point they were further randomised to either } \\
\text { continue with their diet or terminate dietary restrictions. Participants were then monitored until at } \\
\text { least their } 12 \text { th birthday. }\end{array}$
\end{tabular}

\begin{tabular}{ll}
\hline Outcomes & $\begin{array}{l}\text { Blood phenylalanine level. } \\
\text { Growth and nutritional indices. } \\
\text { Nutritional intake. } \\
\text { IQ and neuropsychological performance. }\end{array}$ \\
\hline Notes & $\begin{array}{l}\text { Data was combined in several reports of the study therefore it was not possible to analyse the differ- } \\
\text { ence between treatment and control group. The trialists have been contacted for further details. }\end{array}$
\end{tabular}

\section{Risk of bias}

\begin{tabular}{|c|c|c|}
\hline Bias & Authors' judgement & Support for judgement \\
\hline $\begin{array}{l}\text { Adequate sequence gener- } \\
\text { ation? }\end{array}$ & Low risk & Treatment groups "randomly formed" using table of random numbers. \\
\hline Allocation concealment? & Low risk & $\begin{array}{l}\text { Allocation schedule produced by project staff in telephone contact with local } \\
\text { clinic staff at participating clinics. }\end{array}$ \\
\hline $\begin{array}{l}\text { Blinding? } \\
\text { Participants }\end{array}$ & High risk & Not blinded. \\
\hline $\begin{array}{l}\text { Blinding? } \\
\text { Clinicians }\end{array}$ & High risk & Not blinded. \\
\hline $\begin{array}{l}\text { Blinding? } \\
\text { Outcome assessors }\end{array}$ & Low risk & $\begin{array}{l}\text { Laboratory analysis at local clinics checked by two reference laboratories. } \\
\text { EEGs read at local clinic and Project centre, discrepancies resolved by 'blind } \\
\text { reading' by independent third encelphalographer. }\end{array}$ \\
\hline $\begin{array}{l}\text { Incomplete outcome data } \\
\text { addressed? } \\
\text { All outcomes }\end{array}$ & Unclear risk & $\begin{array}{l}\text { A relatively high proportion of participants were lost to follow up (reasons giv- } \\
\text { en) and some participants swapped groups after randomisation (US/PKU Col- } \\
\text { laborative). }\end{array}$ \\
\hline
\end{tabular}

EEG: electroencephalography

PKU: phenylketonuria

Characteristics of excluded studies [ordered by study ID]

\begin{tabular}{ll}
\hline Study & Reason for exclusion \\
\hline Bentovim 1968 & Unclear if randomised and dietary treatment not initiated soon after birth in all participants. \\
\hline Cleary 2006 & Trial of a specific supplement. \\
\hline Epstein 1989 & Not a randomised controlled trial. \\
\hline Frankenburg 1973 & Not a randomised controlled trial. \\
\hline
\end{tabular}




\begin{tabular}{|c|c|}
\hline Study & Reason for exclusion \\
\hline Kakanoglu 2005 & Participants not eligible - paper states 'participants previously untreated'. \\
\hline Koff 1979 & Not a randomised controlled trial. \\
\hline Koletzko 2007 & Trial of a fatty acid supplement. \\
\hline Krause 1985 & Not a randomised controlled trial. \\
\hline Levy 2007 & Trial of a specific supplement. \\
\hline Lou 1987 & Trial of an additional supplement. \\
\hline Pietz 1995 & Trial of tyrosine. \\
\hline Realmuto 1986 & Introduced phenylalanine for one day only. \\
\hline Rey 1996 & Not a randomised controlled trial. \\
\hline Robertson 2004 & Participants previously untreated. \\
\hline Schindeler 2007 & Trial of an additional supplement. \\
\hline Schmidt 1994 & Not a randomised controlled trial. \\
\hline Schmidt 1996 & Not a randomised controlled trial. \\
\hline Smith 1998 & Trial of tyrosine. \\
\hline
\end{tabular}

\section{DATA AND ANALYSES}

\section{Comparison 1. PKU participants started on diet at diagnosis: Diet continuation versus discontinuation/relaxation later}

\begin{tabular}{|c|c|c|c|c|}
\hline Outcome or subgroup title & $\begin{array}{l}\text { No. of } \\
\text { studies }\end{array}$ & $\begin{array}{l}\text { No. of } \\
\text { partici- } \\
\text { pants }\end{array}$ & Statistical method & Effect size \\
\hline 1 Blood phenylalanine level (micromol/l) & 3 & & $\begin{array}{l}\text { Mean Difference (IV, Fixed, } \\
95 \% \mathrm{CI})\end{array}$ & Subtotals only \\
\hline 1.1 Blood phenylalanine level ( 0 to 3 months) & 2 & 41 & $\begin{array}{l}\text { Mean Difference (IV, Fixed, } \\
95 \% \mathrm{CI})\end{array}$ & $-698.67[-869.44,-527.89]$ \\
\hline 1.2 Blood phenylalanine level ( 4 to 6 months) & 1 & 10 & $\begin{array}{l}\text { Mean Difference (IV, Fixed, } \\
95 \% \mathrm{Cl} \text { ) }\end{array}$ & $\begin{array}{l}-871.20[-1261.53 \\
-480.87]\end{array}$ \\
\hline $\begin{array}{l}1.3 \text { Blood phenylalanine level ( } 7 \text { to } 12 \\
\text { months) }\end{array}$ & 1 & 10 & $\begin{array}{l}\text { Mean Difference (IV, Fixed, } \\
95 \% \mathrm{CI})\end{array}$ & $-913.5[-1370.42,-456.58]$ \\
\hline 1.4 Blood phenylalanine level (>12 months) & 2 & 90 & $\begin{array}{l}\text { Mean Difference (IV, Fixed, } \\
95 \% \mathrm{CI})\end{array}$ & $-751.54[-883.41,-619.67]$ \\
\hline
\end{tabular}




\begin{tabular}{|c|c|c|c|c|}
\hline Outcome or subgroup title & $\begin{array}{l}\text { No. of } \\
\text { studies }\end{array}$ & $\begin{array}{l}\text { No. of } \\
\text { partici- } \\
\text { pants }\end{array}$ & Statistical method & Effect size \\
\hline 2 Weight & 1 & & $\begin{array}{l}\text { Mean Difference (IV, Fixed, } \\
95 \% \mathrm{CI} \text { ) }\end{array}$ & Subtotals only \\
\hline 2.1 Weight ( 0 to 3 month) & 1 & 88 & $\begin{array}{l}\text { Mean Difference (IV, Fixed, } \\
95 \% \mathrm{CI} \text { ) }\end{array}$ & $-0.20[-0.47,0.07]$ \\
\hline 2.2 Weight (4 to 6 months) & 1 & 88 & $\begin{array}{l}\text { Mean Difference (IV, Fixed, } \\
95 \% \mathrm{CI} \text { ) }\end{array}$ & $-0.20[-0.56,0.16]$ \\
\hline 2.3 Weight ( 7 to 12 months) & 1 & 88 & $\begin{array}{l}\text { Mean Difference (IV, Fixed, } \\
95 \% \mathrm{CI} \text { ) }\end{array}$ & $-0.10[-0.58,0.38]$ \\
\hline 3 Intelligence Quotient (IQ) & 1 & & $\begin{array}{l}\text { Mean Difference (IV, Fixed, } \\
95 \% \mathrm{CI} \text { ) }\end{array}$ & Subtotals only \\
\hline $3.1 \mathrm{IQ}$ (> 12 months) & 1 & 115 & $\begin{array}{l}\text { Mean Difference (IV, Fixed, } \\
95 \% \mathrm{CI} \text { ) }\end{array}$ & $5.0[0.40,9.60]$ \\
\hline 4 Calorie intake (kcal/kg) & 1 & & $\begin{array}{l}\text { Mean Difference (IV, Fixed, } \\
95 \% \mathrm{CI} \text { ) }\end{array}$ & Subtotals only \\
\hline 4.1 Calorie intake ( 0 to 3 months) & 1 & 88 & $\begin{array}{l}\text { Mean Difference (IV, Fixed, } \\
95 \% \mathrm{CI} \text { ) }\end{array}$ & $-1.0[-11.06,9.06]$ \\
\hline 4.2 Calorie intake (4 to 6 months) & 1 & 88 & $\begin{array}{l}\text { Mean Difference (IV, Fixed, } \\
95 \% \mathrm{CI})\end{array}$ & $-3.0[-10.12,4.12]$ \\
\hline 4.3 Calorie intake ( 7 to 12 months) & 1 & 88 & $\begin{array}{l}\text { Mean Difference (IV, Fixed, } \\
95 \% \mathrm{CI} \text { ) }\end{array}$ & $-6.0[-12.51,0.51]$ \\
\hline 5 Protein intake $(\mathrm{g} / \mathrm{kg})$ & 1 & & $\begin{array}{l}\text { Mean Difference (IV, Fixed, } \\
95 \% \mathrm{CI} \text { ) }\end{array}$ & Subtotals only \\
\hline 5.1 Protein intake ( 0 to 3 months) & 1 & 88 & $\begin{array}{l}\text { Mean Difference (IV, Fixed, } \\
95 \% \mathrm{CI})\end{array}$ & $0.0[-0.40,0.40]$ \\
\hline 5.2 Protein intake (4 to 6 months) & 1 & 88 & $\begin{array}{l}\text { Mean Difference (IV, Fixed, } \\
95 \% \mathrm{CI} \text { ) }\end{array}$ & $-0.10[-0.33,0.13]$ \\
\hline 5.3 Protein intake ( 7 to 12 months) & 1 & 88 & $\begin{array}{l}\text { Mean Difference (IV, Fixed, } \\
95 \% \mathrm{CI})\end{array}$ & $-0.10[-0.31,0.11]$ \\
\hline
\end{tabular}

\section{Analysis 1.1. Comparison 1 PKU participants started on diet at diagnosis: Diet continuation versus discontinuation/relaxation later, Outcome 1 Blood phenylalanine level (micromol/l).}

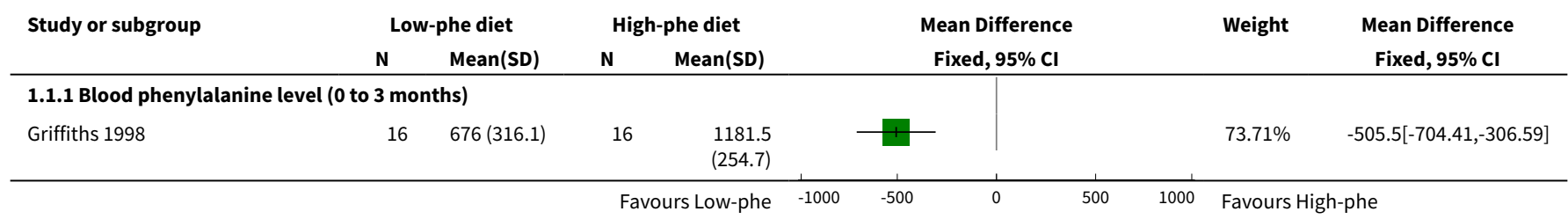




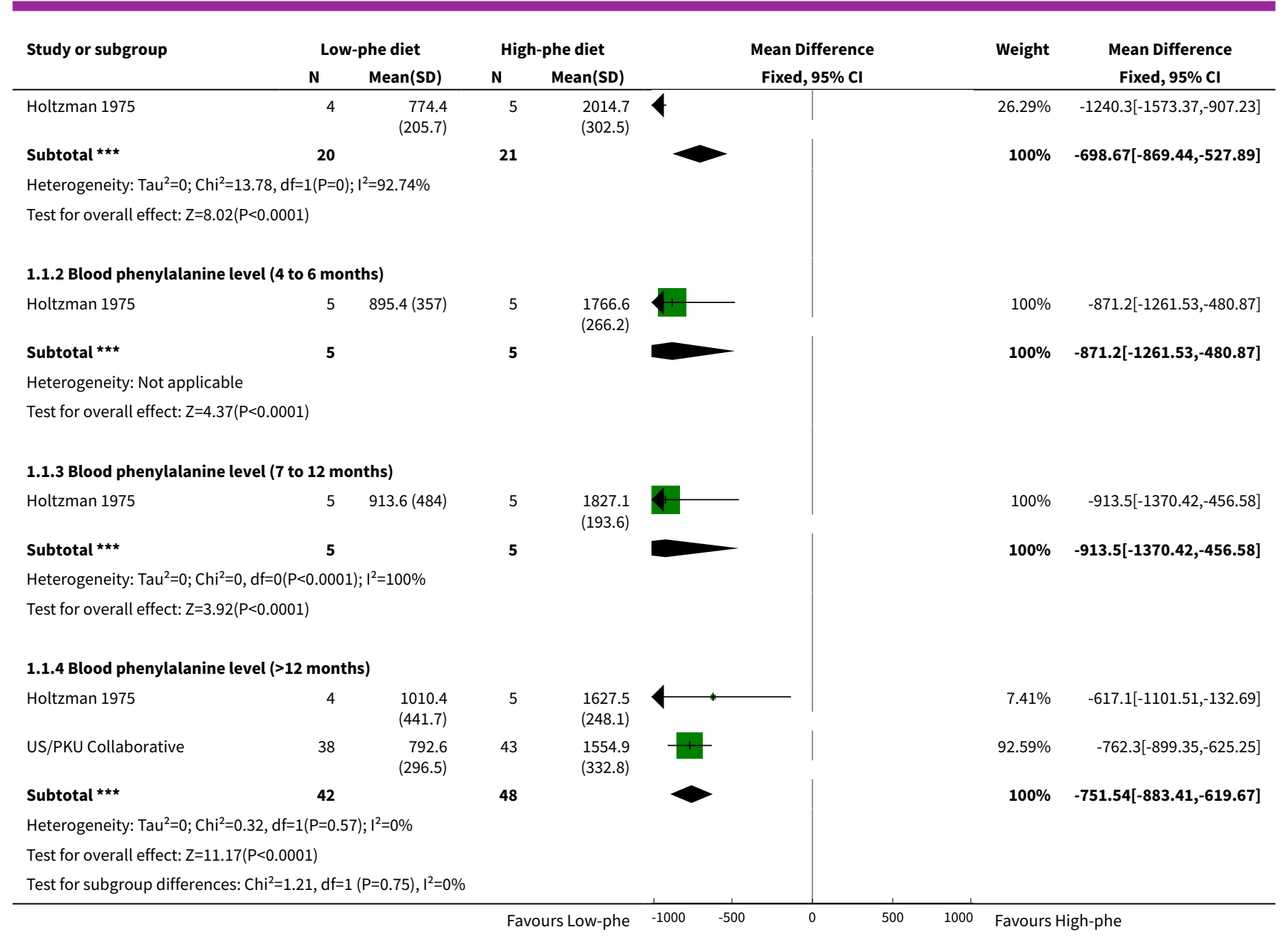

Analysis 1.2. Comparison 1 PKU participants started on diet at diagnosis: Diet continuation versus discontinuation/relaxation later, Outcome 2 Weight.

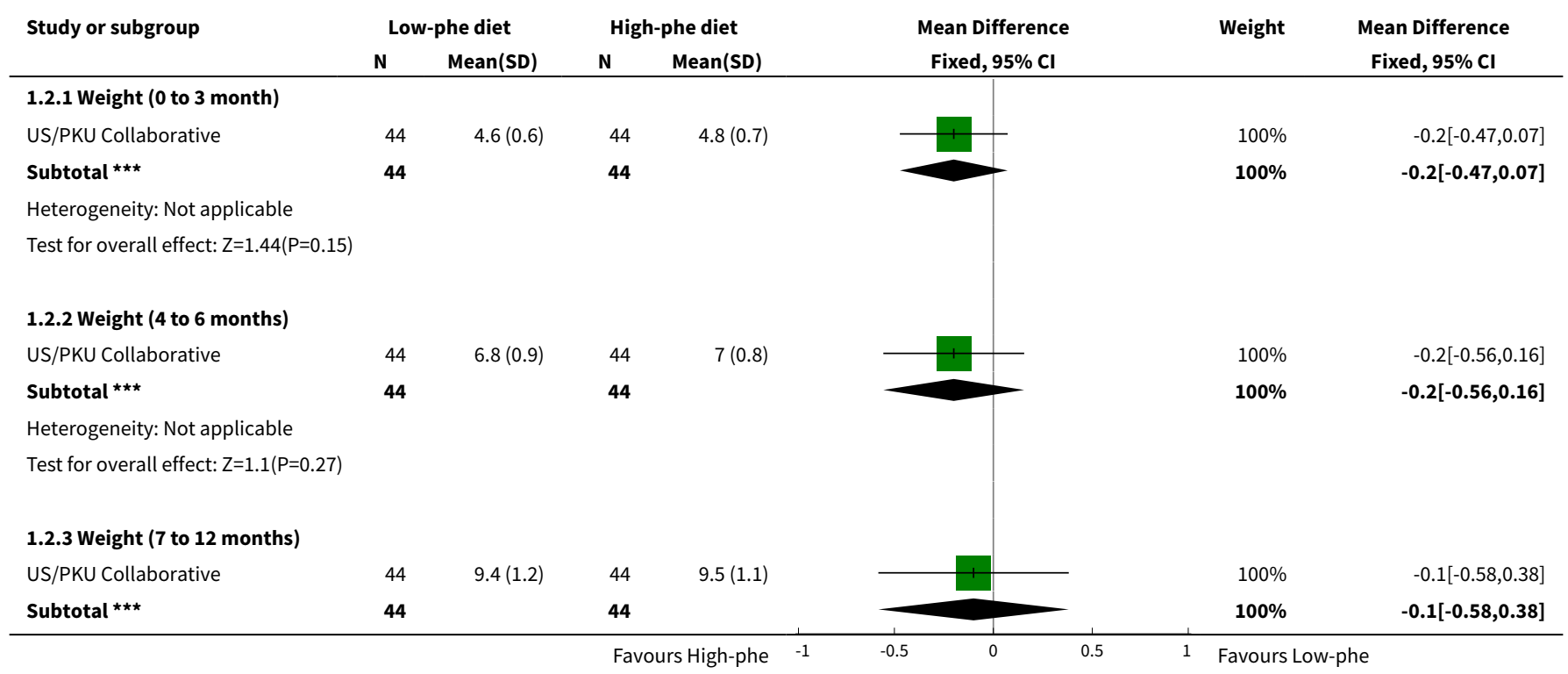




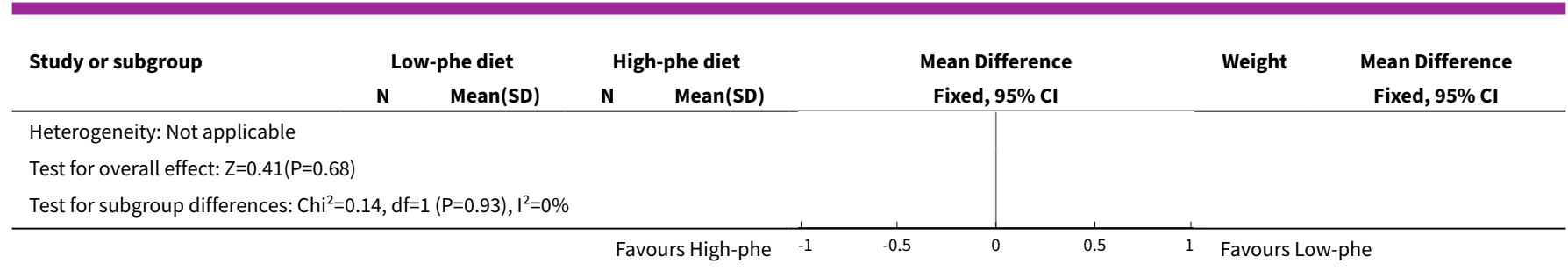

Analysis 1.3. Comparison 1 PKU participants started on diet at diagnosis: Diet continuation versus discontinuation/relaxation later, Outcome 3 Intelligence Quotient (IQ).

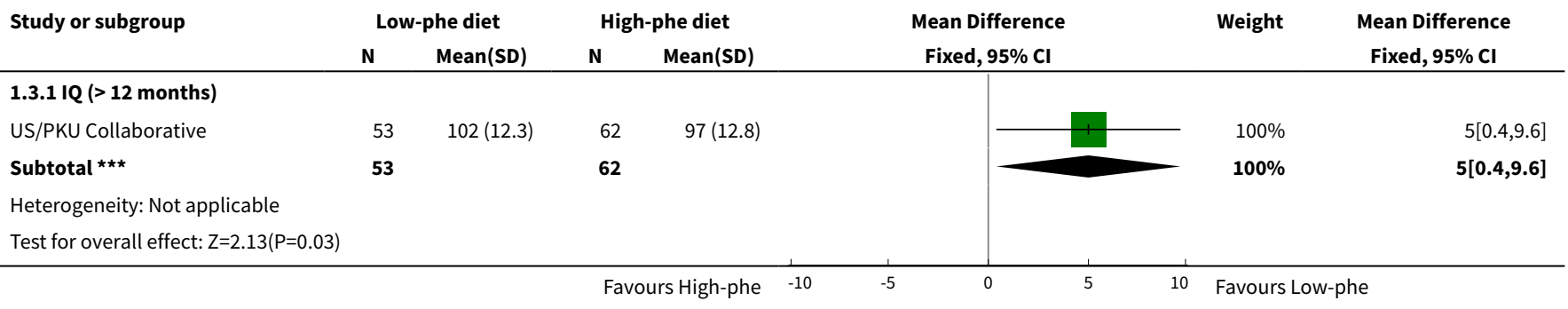

Analysis 1.4. Comparison 1 PKU participants started on diet at diagnosis: Diet continuation versus discontinuation/relaxation later, Outcome 4 Calorie intake (kcal/kg).

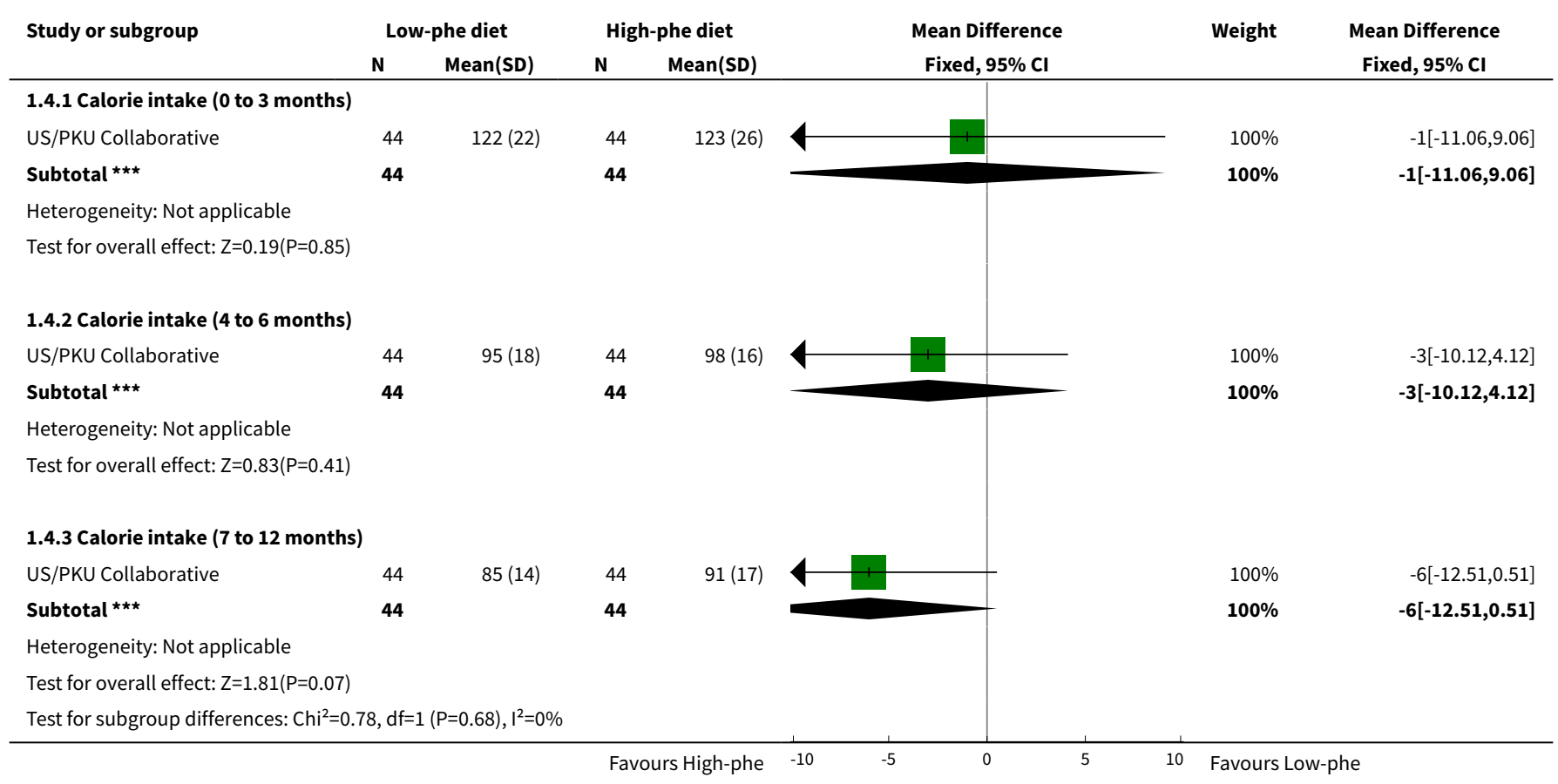


Analysis 1.5. Comparison 1 PKU participants started on diet at diagnosis: Diet continuation versus discontinuation/relaxation later, Outcome 5 Protein intake (g/kg).

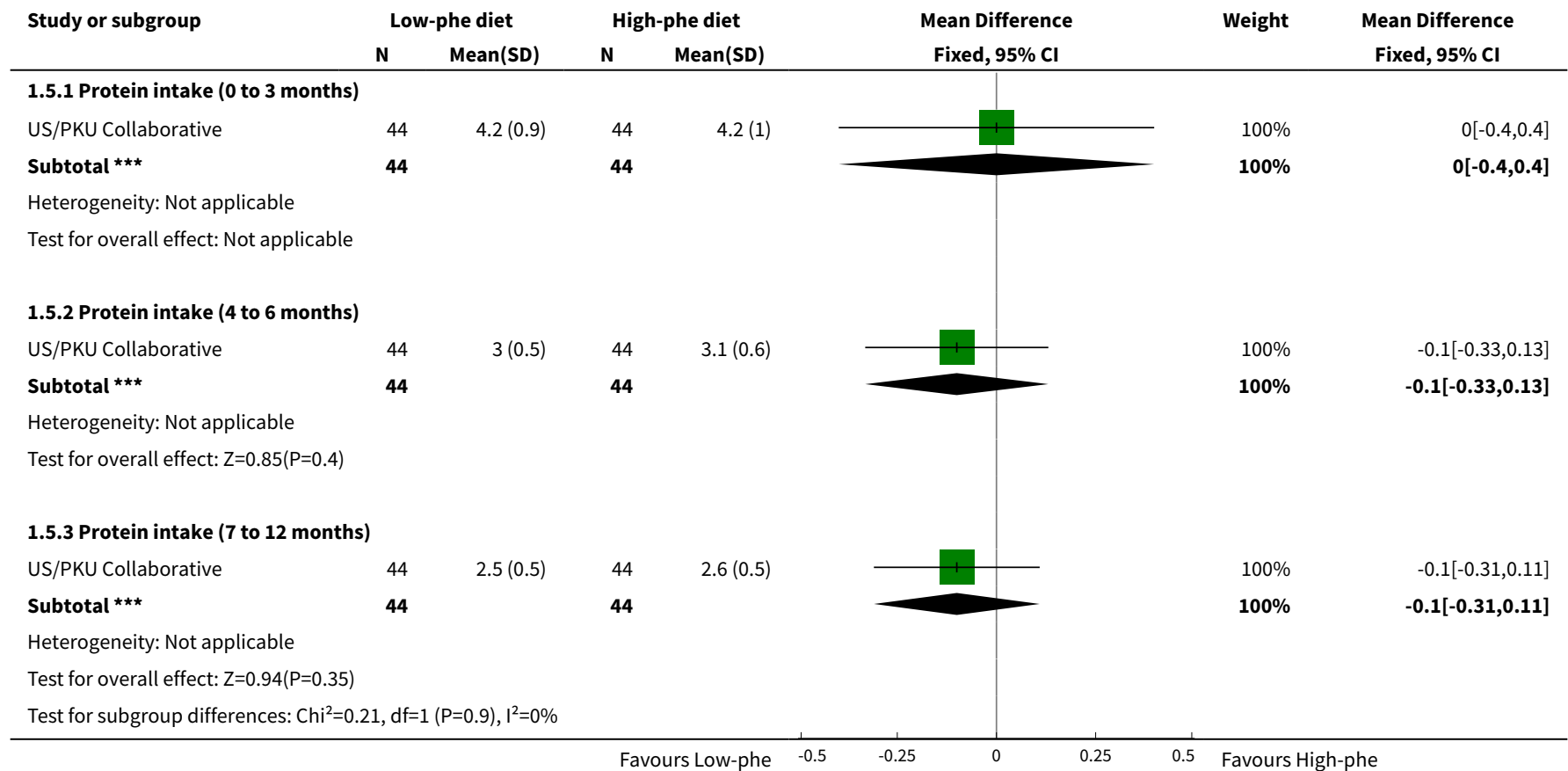

Comparison 2. PKU participants on strict diet from diagnosis, later relaxed: Diet re-establishment versus continuation

\begin{tabular}{lllll}
\hline Outcome or subgroup title & $\begin{array}{l}\text { No. of } \\
\text { studies }\end{array}$ & $\begin{array}{l}\text { No. of } \\
\text { partici- } \\
\text { pants }\end{array}$ & Statistical method & Effect size \\
\hline $\begin{array}{l}1 \text { Blood phenylalanine level (micro- } \\
\text { mol/l) }\end{array}$ & 1 & & Mean Difference (IV, Fixed, 95\% Cl) & Subtotals only \\
\hline $\begin{array}{l}1.1 \text { Blood phenylalanine level (0 to } 3 \\
\text { months) }\end{array}$ & 1 & 18 & Mean Difference (IV, Fixed, 95\% Cl) & $-614.0[-867.27$, \\
\hline
\end{tabular}

Analysis 2.1. Comparison 2 PKU participants on strict diet from diagnosis, later relaxed: Diet re-establishment versus continuation, Outcome 1 Blood phenylalanine level (micromol/l).

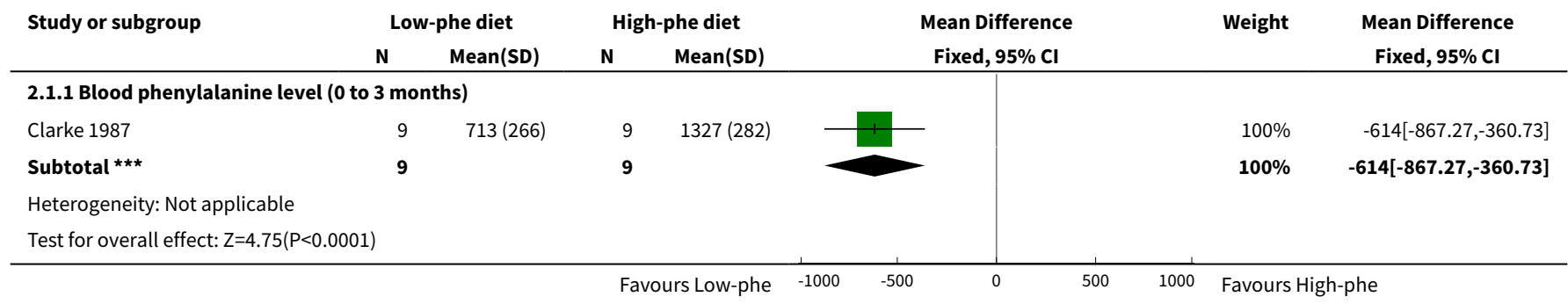


Comparison 3. PKU participants at diagnosis: Low-phenylalanine diet versus moderate phenylalanine diet

\begin{tabular}{|c|c|c|c|c|}
\hline Outcome or subgroup title & $\begin{array}{l}\text { No. of } \\
\text { studies }\end{array}$ & $\begin{array}{l}\text { No. of } \\
\text { partici- } \\
\text { pants }\end{array}$ & Statistical method & Effect size \\
\hline 1 Blood phenylalanine level (micromol/l) & 1 & & $\begin{array}{l}\text { Mean Difference (IV, Fixed, } \\
95 \% \mathrm{CI})\end{array}$ & Subtotals only \\
\hline $\begin{array}{l}1.1 \text { Blood phenylalanine level ( } 0 \text { to } 3 \\
\text { months) }\end{array}$ & 1 & 132 & $\begin{array}{l}\text { Mean Difference (IV, Fixed, } \\
95 \% \mathrm{CI})\end{array}$ & $-127.10[-185.04,-69.16]$ \\
\hline $\begin{array}{l}1.2 \text { Blood phenylalanine levels ( } 7 \text { to } 12 \\
\text { months) }\end{array}$ & 1 & 132 & $\begin{array}{l}\text { Mean Difference (IV, Fixed, } \\
95 \% \mathrm{CI})\end{array}$ & $-157.3[-217.18,-97.42]$ \\
\hline 1.3 Blood phenylalanine level (at 2 years) & 1 & 132 & $\begin{array}{l}\text { Mean Difference (IV, Fixed, } \\
95 \% \mathrm{CI})\end{array}$ & $-84.70[-158.02,-11.38]$ \\
\hline 1.4 Blood phenylalanine level (at 3 years) & 1 & 128 & $\begin{array}{l}\text { Mean Difference (IV, Fixed, } \\
95 \% \mathrm{CI})\end{array}$ & $-48.40[-125.39,28.59]$ \\
\hline 1.5 Blood phenylalanine level (at 4 years) & 1 & 127 & $\begin{array}{l}\text { Mean Difference (IV, Fixed, } \\
95 \% \mathrm{CI})\end{array}$ & $-78.70[-174.49,17.09]$ \\
\hline 1.6 Blood phenylalanine level (at 5 years) & 1 & 127 & $\begin{array}{l}\text { Mean Difference (IV, Fixed, } \\
95 \% \mathrm{CI})\end{array}$ & $-72.60[-162.35,17.15]$ \\
\hline 2 Weight (kg) & 1 & & $\begin{array}{l}\text { Mean Difference (IV, Fixed, } \\
95 \% \mathrm{CI})\end{array}$ & Subtotals only \\
\hline 2.1 Weight (0 to 3 months) & 1 & 88 & $\begin{array}{l}\text { Mean Difference (IV, Fixed, } \\
95 \% \mathrm{CI})\end{array}$ & $-0.20[-0.47,0.07]$ \\
\hline 2.2 Weight (4 to 6 months) & 1 & 88 & $\begin{array}{l}\text { Mean Difference (IV, Fixed, } \\
95 \% \mathrm{CI})\end{array}$ & $-0.20[-0.56,0.16]$ \\
\hline 2.3 Weight ( 7 to 12 months) & 1 & 88 & $\begin{array}{l}\text { Mean Difference (IV, Fixed, } \\
95 \% \mathrm{CI})\end{array}$ & $-0.10[-0.58,0.38]$ \\
\hline 3 Intelligence Quotient (IQ) & 1 & & $\begin{array}{l}\text { Mean Difference (IV, Fixed, } \\
95 \% \mathrm{CI})\end{array}$ & Subtotals only \\
\hline $3.1 \mathrm{IQ}$ at 4 years & 1 & 111 & $\begin{array}{l}\text { Mean Difference (IV, Fixed, } \\
95 \% \mathrm{CI})\end{array}$ & $3.00[-2.77,8.77]$ \\
\hline $3.2 \mathrm{IQ}$ at 6 years & 1 & 132 & $\begin{array}{l}\text { Mean Difference (IV, Fixed, } \\
95 \% \mathrm{CI})\end{array}$ & $2.0[-3.41,7.41]$ \\
\hline 4 Calorie intake (kcal/kg) & 1 & & $\begin{array}{l}\text { Mean Difference (IV, Fixed, } \\
95 \% \mathrm{CI})\end{array}$ & Subtotals only \\
\hline 4.1 Calorie intake ( 0 to 3 months) & 1 & 88 & $\begin{array}{l}\text { Mean Difference (IV, Fixed, } \\
95 \% \mathrm{CI})\end{array}$ & $-1.0[-11.06,9.06]$ \\
\hline 4.2 Calorie intake ( 4 to 6 months) & 1 & 88 & $\begin{array}{l}\text { Mean Difference (IV, Fixed, } \\
95 \% \mathrm{CI})\end{array}$ & $-3.0[-10.12,4.12]$ \\
\hline
\end{tabular}




\begin{tabular}{|c|c|c|c|c|}
\hline Outcome or subgroup title & $\begin{array}{l}\text { No. of } \\
\text { studies }\end{array}$ & $\begin{array}{l}\text { No. of } \\
\text { partici- } \\
\text { pants }\end{array}$ & Statistical method & Effect size \\
\hline 4.3 Calorie intake ( 7 to 12 months) & 1 & 88 & $\begin{array}{l}\text { Mean Difference (IV, Fixed, } \\
95 \% \mathrm{CI})\end{array}$ & $-6.0[-12.51,0.51]$ \\
\hline 5 Protein intake $(\mathrm{g} / \mathrm{kg})$ & 1 & & $\begin{array}{l}\text { Mean Difference (IV, Fixed, } \\
95 \% \mathrm{Cl} \text { ) }\end{array}$ & Subtotals only \\
\hline 5.1 Protein intake ( 0 to 3 months) & 1 & 88 & $\begin{array}{l}\text { Mean Difference (IV, Fixed, } \\
95 \% \mathrm{Cl} \text { ) }\end{array}$ & $0.0[-0.40,0.40]$ \\
\hline 5.2 Protein intake (4 to 6 months) & 1 & 88 & $\begin{array}{l}\text { Mean Difference (IV, Fixed, } \\
95 \% \mathrm{Cl} \text { ) }\end{array}$ & $-0.10[-0.33,0.13]$ \\
\hline 5.3 Protein intake ( 7 to 12 months) & 1 & 88 & $\begin{array}{l}\text { Mean Difference (IV, Fixed, } \\
95 \% \mathrm{CI} \text { ) }\end{array}$ & $-0.10[-0.31,0.11]$ \\
\hline 6 Phenylalanine intake (mg/day) & 1 & & $\begin{array}{l}\text { Mean Difference (IV, Fixed, } \\
95 \% \mathrm{Cl} \text { ) }\end{array}$ & Subtotals only \\
\hline 6.1 At 15 months of age & 1 & 151 & $\begin{array}{l}\text { Mean Difference (IV, Fixed, } \\
95 \% \mathrm{Cl} \text { ) }\end{array}$ & $-64.0[-67.54,-60.46]$ \\
\hline 6.2 At 21 months of age & 1 & 138 & $\begin{array}{l}\text { Mean Difference (IV, Fixed, } \\
95 \% \mathrm{CI} \text { ) }\end{array}$ & $-64.0[-68.81,-59.19]$ \\
\hline 6.3 At 27 months of age & 1 & 141 & $\begin{array}{l}\text { Mean Difference (IV, Fixed, } \\
95 \% \mathrm{CI})\end{array}$ & $-88.0[-92.56,-83.44]$ \\
\hline 6.4 At 33 months of age & 1 & 139 & $\begin{array}{l}\text { Mean Difference (IV, Fixed, } \\
95 \% \mathrm{Cl} \text { ) }\end{array}$ & $-73.0[-77.85,-68.15]$ \\
\hline 6.5 At 39 months of age & 1 & 134 & $\begin{array}{l}\text { Mean Difference (IV, Fixed, } \\
95 \% \mathrm{Cl} \text { ) }\end{array}$ & $-80.0[-84.94,-75.06]$ \\
\hline 6.6 At 45 months of age & 1 & 141 & $\begin{array}{l}\text { Mean Difference (IV, Fixed, } \\
95 \% \mathrm{CI} \text { ) }\end{array}$ & $-58.00[-63.95,-52.05]$ \\
\hline 6.7 At 51 months of age & 1 & 125 & $\begin{array}{l}\text { Mean Difference (IV, Fixed, } \\
95 \% \mathrm{Cl} \text { ) }\end{array}$ & $-83.0[-88.97,-77.03]$ \\
\hline 6.8 At 57 months of age & 1 & 119 & $\begin{array}{l}\text { Mean Difference (IV, Fixed, } \\
95 \% \mathrm{Cl} \text { ) }\end{array}$ & $-69.0[-75.61,-62.39]$ \\
\hline 6.9 At 63 months of age & 1 & 115 & $\begin{array}{l}\text { Mean Difference (IV, Fixed, } \\
95 \% \mathrm{CI})\end{array}$ & $-106.0[-112.54,-99.46]$ \\
\hline 6.10 At 69 months of age & 1 & 117 & $\begin{array}{l}\text { Mean Difference (IV, Fixed, } \\
95 \% \mathrm{CI})\end{array}$ & $-77.0[-90.18,-63.82]$ \\
\hline
\end{tabular}


Analysis 3.1. Comparison 3 PKU participants at diagnosis: Low-phenylalanine diet versus moderate phenylalanine diet, Outcome 1 Blood phenylalanine level (micromol/l).

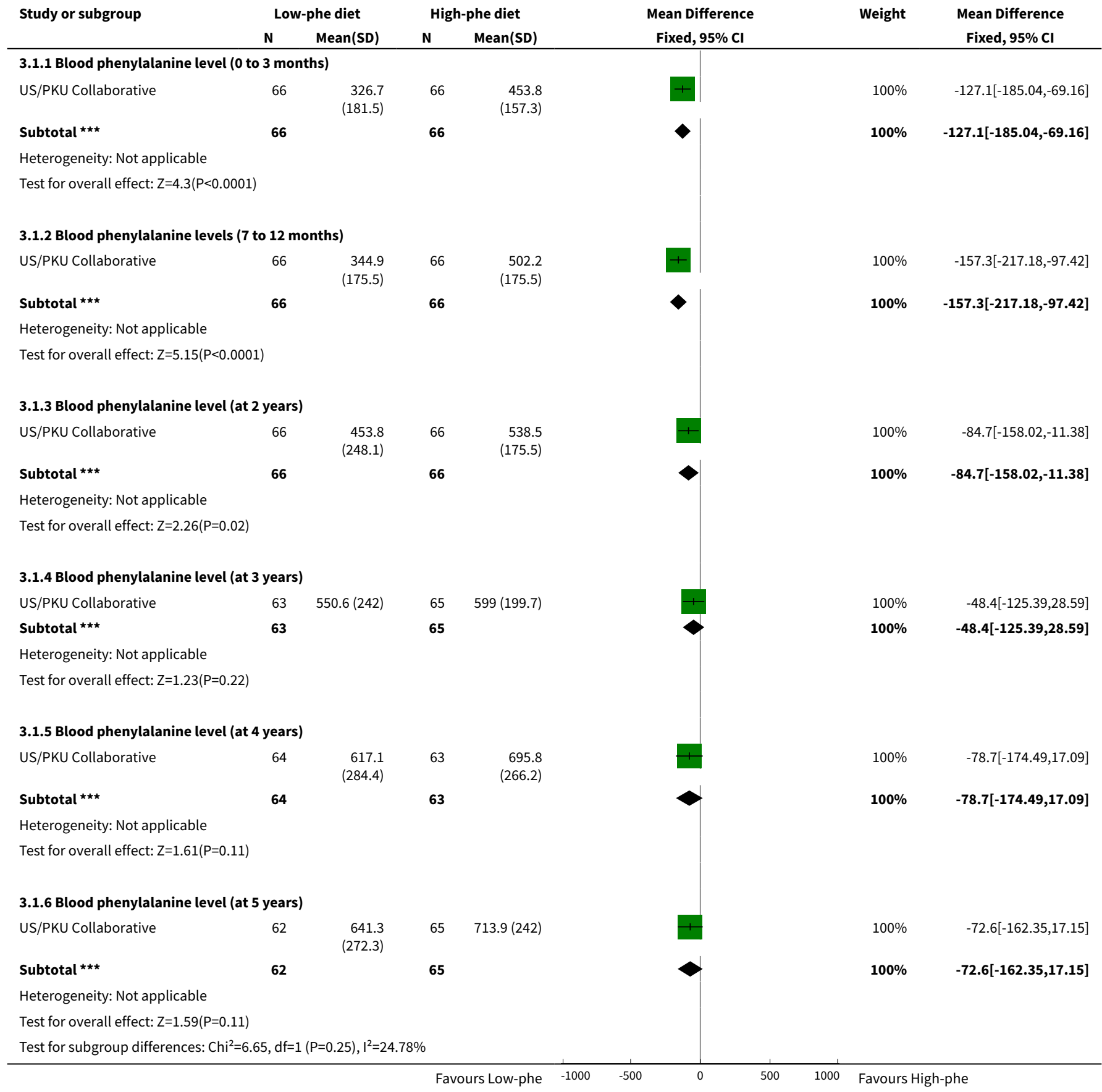


Analysis 3.2. Comparison 3 PKU participants at diagnosis: Low-phenylalanine diet versus moderate phenylalanine diet, Outcome 2 Weight (kg).

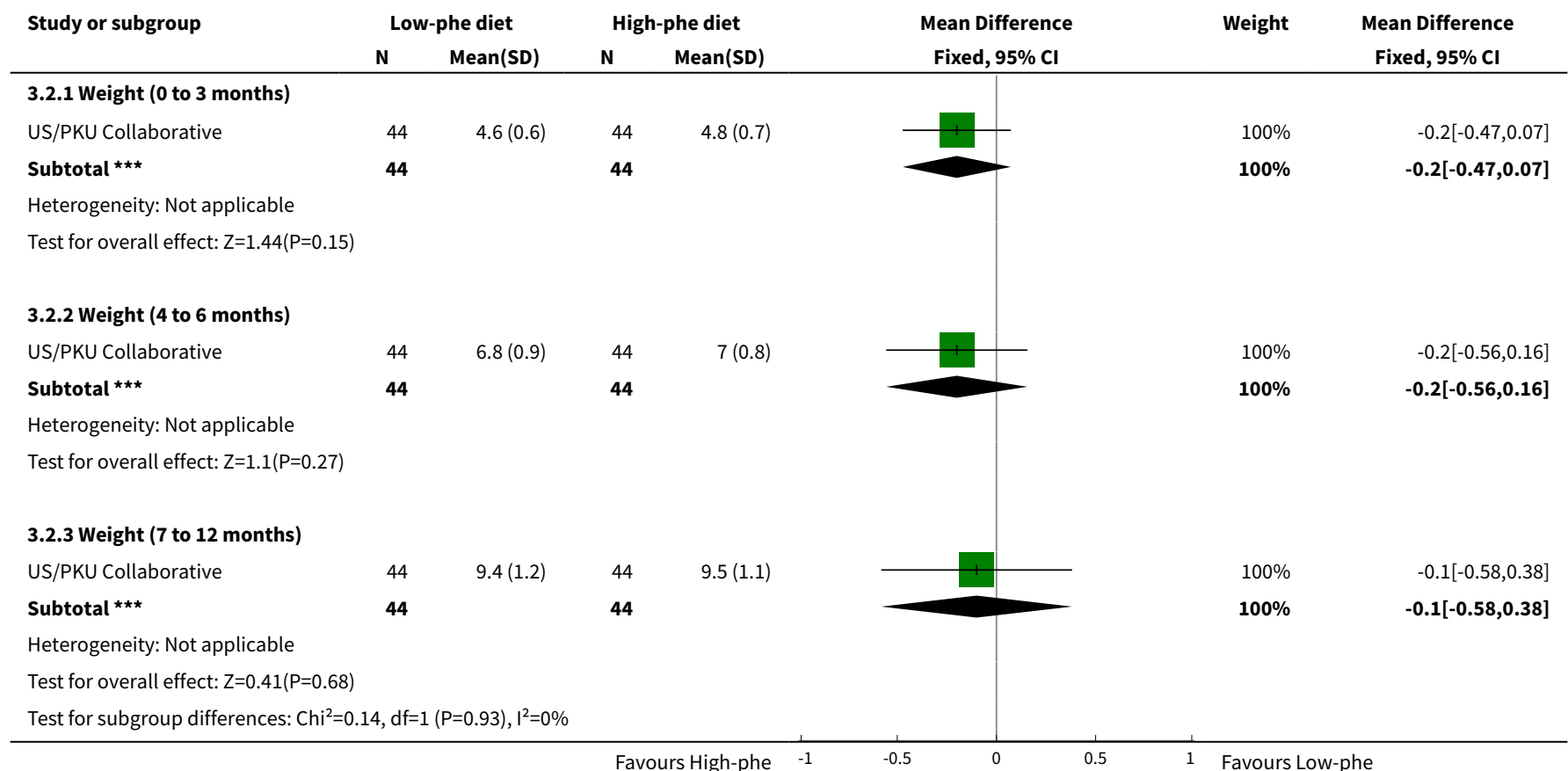

Analysis 3.3. Comparison 3 PKU participants at diagnosis: Low-phenylalanine diet versus moderate phenylalanine diet, Outcome 3 Intelligence Quotient (IQ).

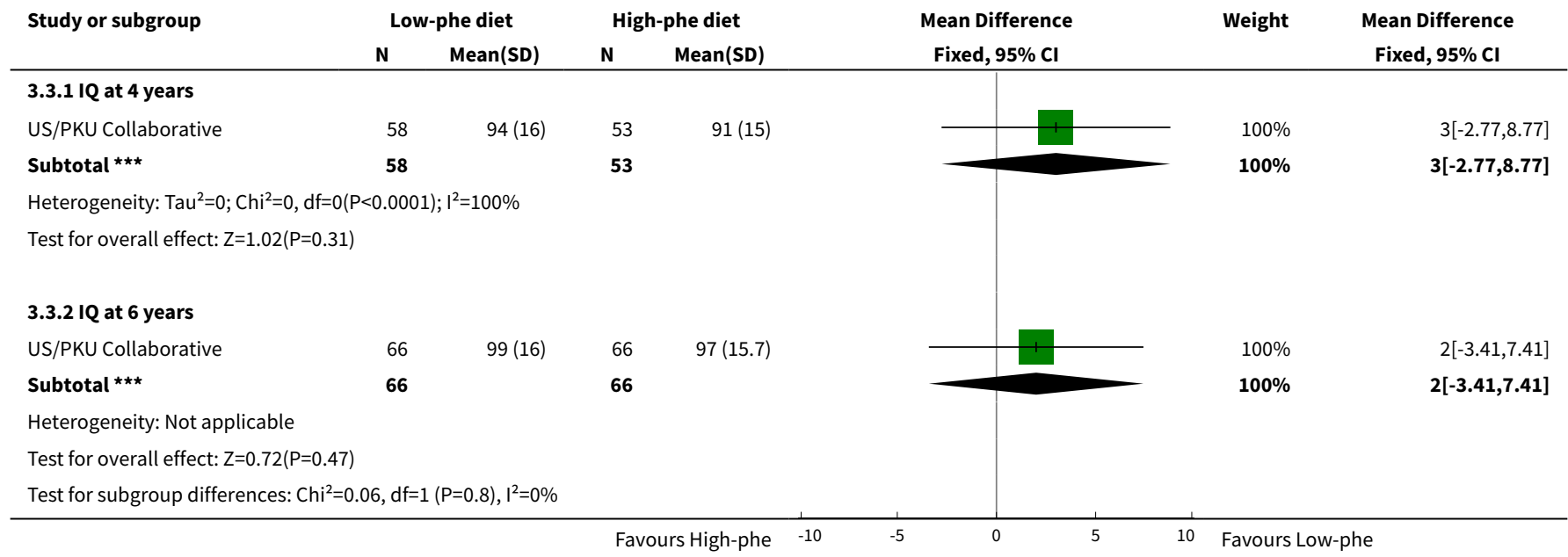


Analysis 3.4. Comparison 3 PKU participants at diagnosis: Low-phenylalanine diet versus moderate phenylalanine diet, Outcome 4 Calorie intake (kcal/kg).

\begin{tabular}{|c|c|c|c|c|c|c|c|}
\hline \multirow[t]{2}{*}{ Study or subgroup } & \multicolumn{2}{|c|}{ Low-phe diet } & \multicolumn{2}{|c|}{ High-phe diet } & \multirow{2}{*}{$\begin{array}{c}\text { Mean Difference } \\
\text { Fixed, } 95 \% \mathrm{Cl}\end{array}$} & \multirow[t]{2}{*}{ Weight } & \multirow{2}{*}{$\begin{array}{l}\text { Mean Difference } \\
\text { Fixed, } 95 \% \mathrm{Cl}\end{array}$} \\
\hline & $\mathbf{N}$ & $\operatorname{Mean}(S D)$ & $\mathbf{N}$ & Mean(SD) & & & \\
\hline \multicolumn{8}{|c|}{ 3.4.1 Calorie intake ( 0 to 3 months) } \\
\hline US/PKU Collaborative & 44 & $122(22)$ & 44 & $123(26)$ & & \multirow{4}{*}{$\begin{array}{l}100 \% \\
\mathbf{1 0 0 \%}\end{array}$} & \multirow{4}{*}{$\begin{array}{r}-1[-11.06,9.06] \\
\mathbf{- 1}[-\mathbf{1 1 . 0 6 , 9 . 0 6}]\end{array}$} \\
\hline Subtotal $* \star \star$ & 44 & & 44 & & & & \\
\hline \multirow{2}{*}{\multicolumn{6}{|c|}{$\begin{array}{l}\text { Heterogeneity: Not applicable } \\
\text { Test for overall effect: } Z=0.19(P=0.85)\end{array}$}} & & \\
\hline & & & & & & & \\
\hline \multicolumn{8}{|c|}{ 3.4.2 Calorie intake ( 4 to 6 months) } \\
\hline US/PKU Collaborative & 44 & $95(18)$ & 44 & $98(16)$ & & \multirow{2}{*}{$\begin{array}{l}100 \% \\
\mathbf{1 0 0} \%\end{array}$} & \multirow{2}{*}{$\begin{array}{r}-3[-10.12,4.12] \\
\mathbf{- 3}[-\mathbf{1 0 . 1 2 , 4 . 1 2}]\end{array}$} \\
\hline Subtotal $* \star \star$ & 44 & & 44 & & & & \\
\hline \multicolumn{8}{|c|}{ Heterogeneity: Not applicable } \\
\hline \multicolumn{8}{|c|}{ Test for overall effect: $Z=0.83(P=0.41)$} \\
\hline US/PKU Collaborative & 44 & $85(14)$ & 44 & $91(17)$ & & \multirow{2}{*}{$\begin{array}{l}100 \% \\
100 \%\end{array}$} & $-6[-12.51,0.51]$ \\
\hline 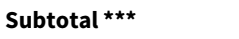 & 44 & & 44 & & & & $-6[-12.51,0.51]$ \\
\hline \multicolumn{8}{|c|}{ Heterogeneity: Not applicable } \\
\hline \multicolumn{8}{|c|}{ Test for overall effect: $Z=1.81(P=0.07)$} \\
\hline \multicolumn{8}{|c|}{ Test for subgroup differences: $\mathrm{Chi}^{2}=0.78, \mathrm{df}=1(\mathrm{P}=0.68), \mathrm{I}^{2}=0 \%$} \\
\hline
\end{tabular}

Analysis 3.5. Comparison 3 PKU participants at diagnosis: Low-phenylalanine diet versus moderate phenylalanine diet, Outcome 5 Protein intake $(\mathrm{g} / \mathrm{kg})$.

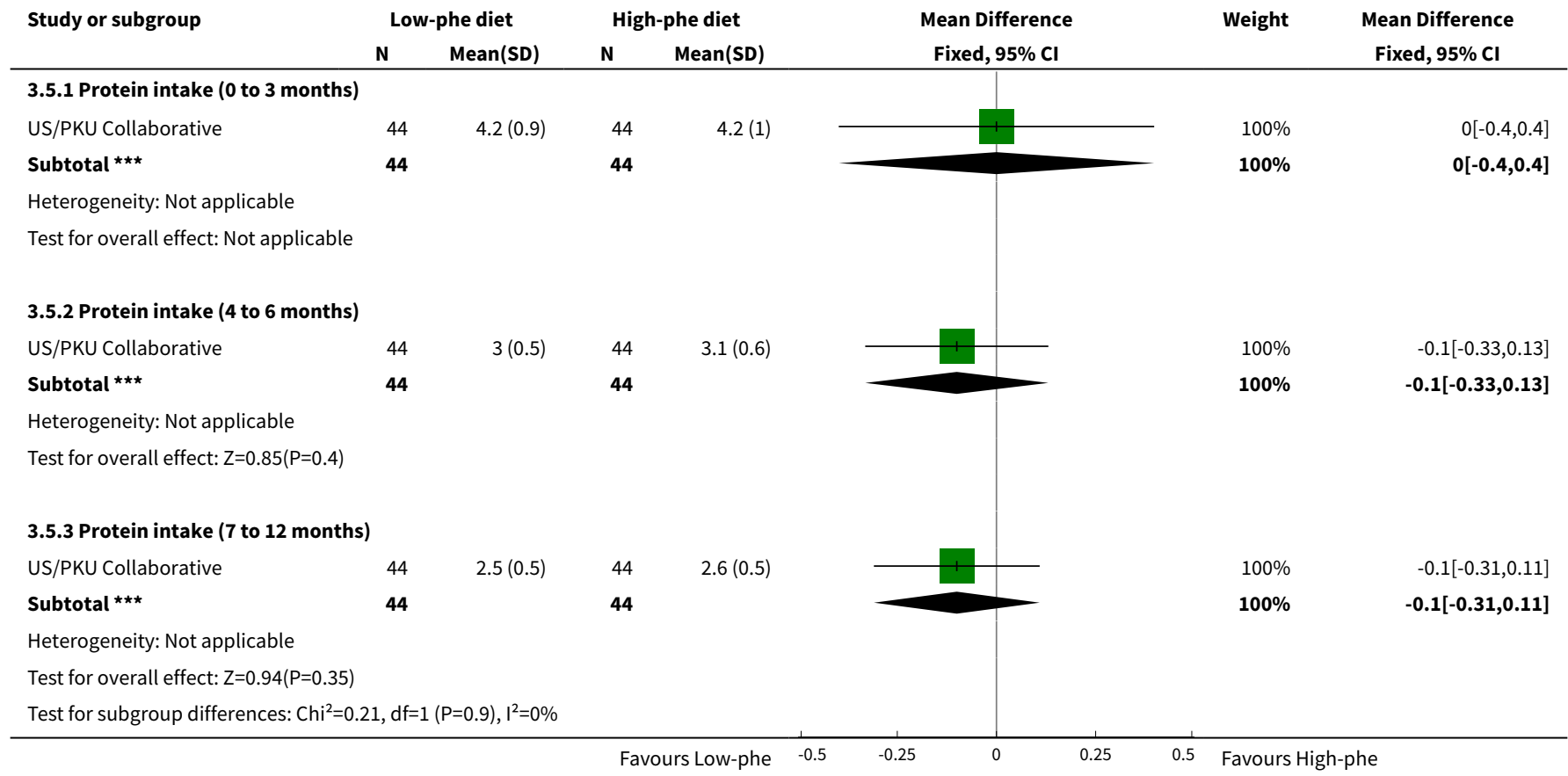


Analysis 3.6. Comparison 3 PKU participants at diagnosis: Low-phenylalanine diet versus moderate phenylalanine diet, Outcome 6 Phenylalanine intake (mg/day).

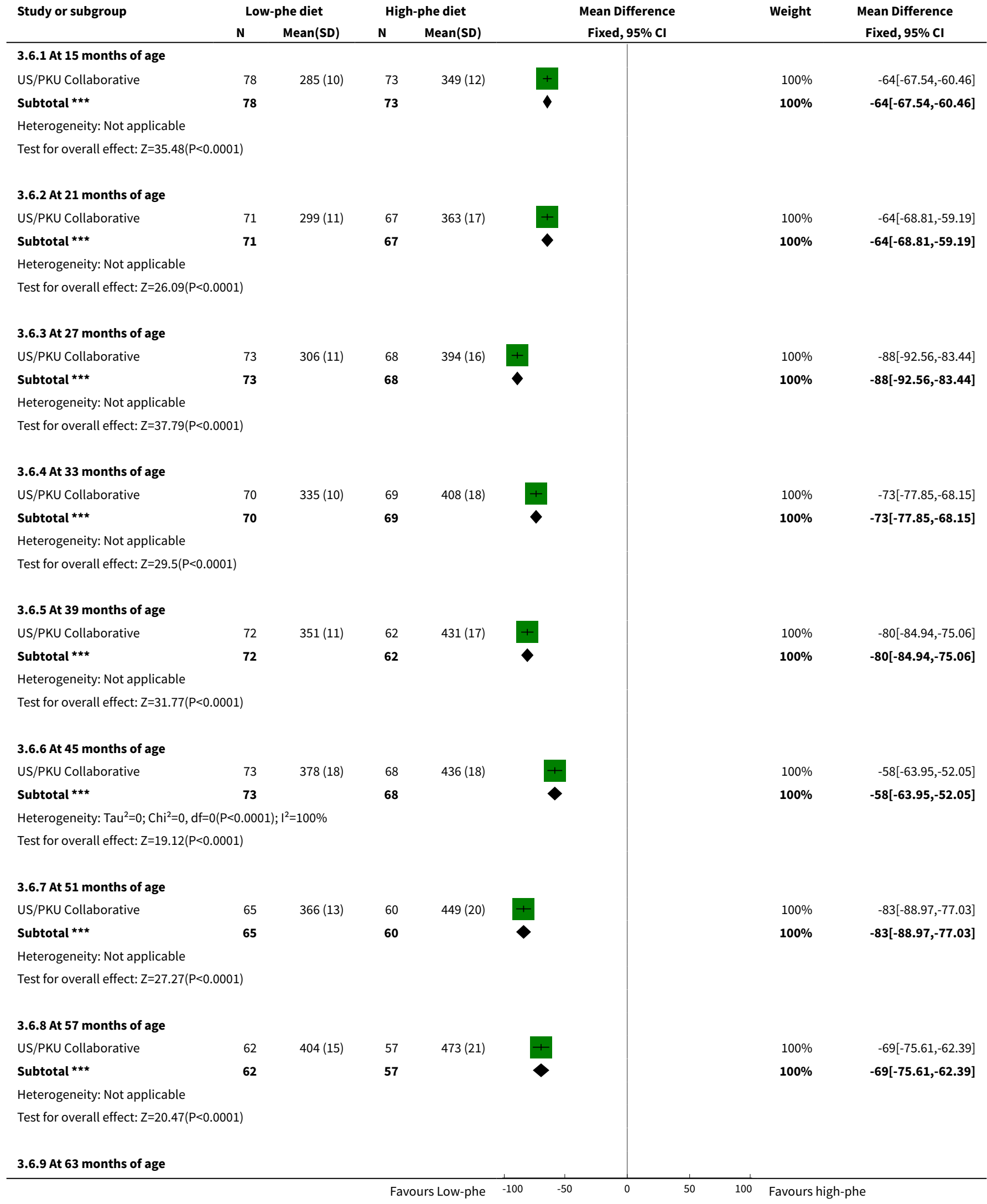




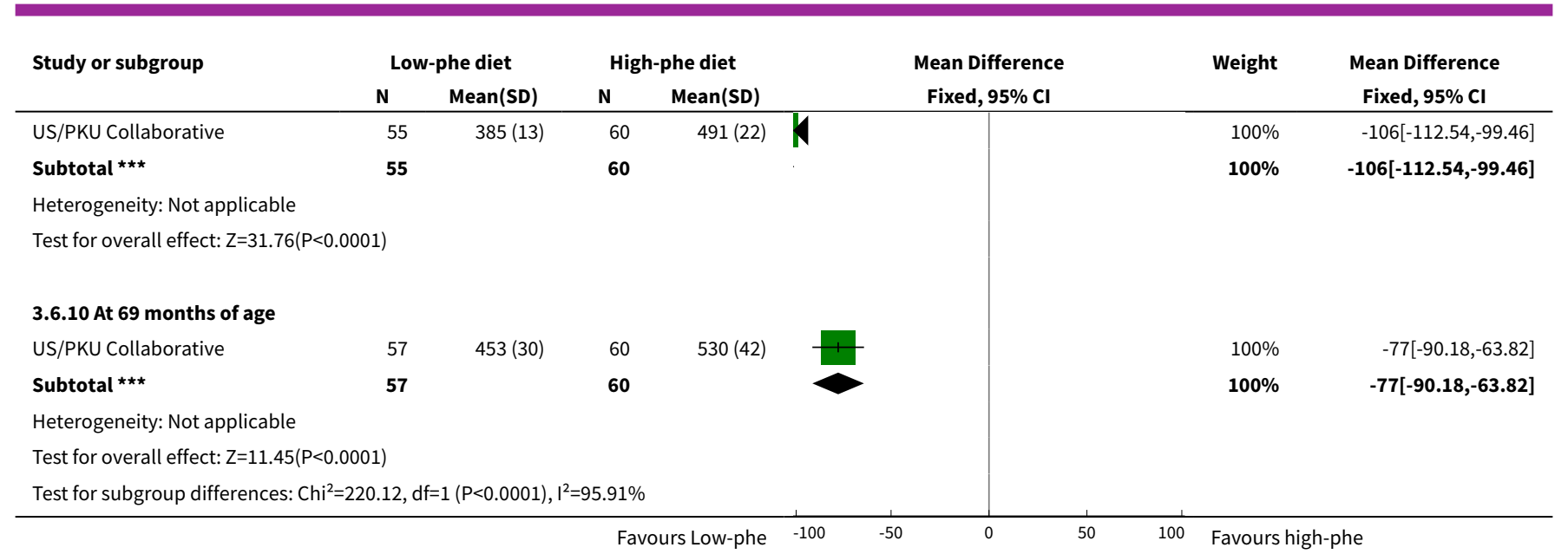

WHAT'S NEW

\begin{tabular}{lll}
\hline Date & Event & Description \\
\hline 21 September 2009 & New search has been performed & $\begin{array}{l}\text { A search of the Group's Inborn Errors of Metabolism Trials Reg- } \\
\text { ister identified nine new references. One reference was an addi- } \\
\text { tional reference to a previously excluded study (Robertson 2004). } \\
\end{array}$ \\
& $\begin{array}{l}\text { Eight references were excluded (Cleary 2006; Kakanoglu 2005; } \\
\text { Koletzko 2007; Levy 2007; Lou 1987; Pietz 1995; Schindeler 2007; } \\
\text { Smith 1998). }\end{array}$
\end{tabular}

\begin{tabular}{lll}
\hline 21 September $2009 \quad$ Amended & $\begin{array}{l}\text { The Plain Language Summary has been updated in light of cur- } \\
\text { rent guidance from The Cochrane Collaboration. }\end{array}$
\end{tabular}

21 September 2009 New citation required but conclusions have not changed

Mrs Patricia Rutherford has stepped down as author from this update of the review.

\section{HISTORY}

Protocol first published: Issue 4, 1998

Review first published: Issue 3, 1999

\begin{tabular}{lll}
\hline Date & Event & Description \\
\hline 6 November 2008 & Amended & Converted to new review format. \\
\hline 5 May 2007 & New search has been performed & $\begin{array}{l}\text { A new search of the Group's Inborn Errors of Metabolism Trials } \\
\text { Register identified six references which were found not to be eli- } \\
\text { gible for inclusion in the review. }\end{array}$ \\
\hline
\end{tabular}

\begin{tabular}{ll}
\hline 31 March $2006 \quad$ New search has been performed & $\begin{array}{l}\text { A new search of the group's register identified two references to } \\
\text { one study which has been listed under Excluded studies (Robert- } \\
\text { son 2004). }\end{array}$
\end{tabular}

5 April $2004 \quad$ New search has been performed

The search for trials identified one further reference to the already included US/PKU Collaborative 1997 trial. This reference contained no further data for inclusion in the review. 


\begin{tabular}{lll}
\hline Date & Event & Description \\
\hline 6 February 2003 New search has been performed & $\begin{array}{l}\text { Two further publications containing data from one of the includ- } \\
\text { ed studies (US/PKU Collaborative) have been identified. Only da- } \\
\text { ta relating to phenylalanine intake could be extracted from these } \\
\text { for inclusion in the review. The inclusion of these data does not } \\
\text { affect the overall results of this review. }\end{array}$ \\
\end{tabular}

\section{CONTRIBUTIONS OF AUTHORS}

For production of the initial review and the updates until 2006:

Vanessa Poustie:

1. identification of trials from Cochrane Cystic Fibrosis \& Genetic Disorders Group Trials Register;

2. handsearching of the Journal of Inherited Metabolic Disease from 1979 to 1998;

3. further identification of trials from publication reference lists;

4. selection of eligible trials;

5. assessment of trial methodology;

6. extraction of relevant data from the trials;

7. input of trial data;

8. production of the final review;

9. updating review.

Patricia Rutherford:

1. selection of eligible trials;

2. assessment of trial methodology;

3. extraction of relevant data from the trials;

4. comment on final draft of review;

5. comment on updates of review up to and including 2006 update.

Update 2007:

Vanessa Poustie remains as lead author and was involved in study selection.

Patricia Rutherford is no longer an active author on this review.

Joanne Wildgoose is now a new author on this review and was involved in study selection.

\section{DECLARATIONS OF INTEREST}

Vanessa Poustie and Patricia Rutherford have received travel expenses to attend conferences from the manufacturers of dietary products used in the treatment of PKU.

\section{SOURCES OF SUPPORT}

\section{Internal sources}

- No sources of support supplied

\section{External sources}

- North West NHS Executive Research \& Development Directorate Training Fellowship Scheme, UK.

- British Dietetic Association General Education Trust, UK.

\section{NOTES}

Within this review we have chosen to report the primary outcomes: blood phenylalanine concentration; and blood tyrosine concentration in micromol/l.

Therefore, we have used the following conversions on data reported in several of the primary papers that report $\mathrm{mg} / \mathrm{dl}$ : 
Phenylalanine $-1 \mathrm{mg} / \mathrm{dl}=60.5 \mathrm{micromol} / \mathrm{l}$

Tyrosine $-1 \mathrm{mg} / \mathrm{dl}=55 \mathrm{micromol} / \mathrm{l}$

\section{INDEX TERMS}

\section{Medical Subject Headings (MeSH)}

Phenylalanine [*administration \& dosage] [blood]; Phenylketonurias [blood] [*diet therapy]; Randomized Controlled Trials as Topic; Treatment Outcome

\section{MeSH check words}

Humans 